\title{
Structures of Authority and \\ Comparative Criminal Procedure
}

\author{
Mirjan Damaška
}

\section{TABLE OF CONTENTS}

I. The Hierarchical Model

A. General Characteristics 483

1. The Object of Hierarchy 483

2. The Hierarchical Organization 484

B. The Hierarchical Model and Continental Reality 487

1. Centripetal Decisionmaking 487

2. Rigid Ordering of Authority 498

3. Preference for Determinative Rules $\quad 502$

4. Importance of Official Documents and Reports 506

5. Behavior Expectations 507

II. The Coordinate Model

A. General Characteristics $\quad 509$

1. The Object of Coordination 509

2. The Coordinate Organization 509

B. The Coordinate Model and Anglo-American Reality 511

1. Centrifugal Decisionmaking 511

2. Mild Ordering of Authority 515

3. Preference for Flexible Rules 517

4. The Informal Style 521

5. Behavior Expectations 521

III. The Structure of Authority and the Conventional Typology of Criminal Proceedings

A. The Judge at Trial 523

B. The Complexity of Procedural Issues 526

IV. The Criminal Process and Attitudes toward Political Authority

A. Procedural Models and Political Ideology 529

1. Parental and Arm's Length Criminal Justice $\quad 530$

2. Classic English Liberalism as a Source
for Procedural Choice

B. The Genesis of Divergent Attitudes toward Authority 539

Epilogue

$\dagger$ Professor of Law, University of Pennsylvania. 
It is apparent to the most casual observer that a great divide separates the two systems of criminal procedure devised by Western man over the past eight centuries. When the comparatist turns his view from the Continent to the English speaking world, he encounters contrasts so striking that the great diversity existing within each legal culture pales in significance. Unfortunately, however, although it is an easy matter to enumerate countless striking differences between the two systems, it is far more difficult to investigate the extent to which these differences in detail can be traced to more fundamental differences in the way the two systems conceive of the nature of justice, order, and law itself.

The conventional contrast between the two systems is one that emphasizes the adversarial (or accusatorial) aspects of the Anglo-American process, and the nonadversarial (or inquisitorial) character of the continental mode of proceeding. This dichotomy, no matter how refined, fails to account for many important variations between the two systems, especially if one's focus moves away from the trial stage, and if one discards a preoccupation with legal mythology to consider law as it is actually applied. ${ }^{1}$

In this article I shall argue that previously inexplicable differences between the continental and Anglo-American systems can be understood once the conventional trial-centered models are displaced by another set of organizing concepts. These concepts are intended to suggest that divergences in procedural arrangements are, to a considerable extent, related to larger divergences in the conception of the proper organization of authority characteristic of the Continent and the English-speaking world.

To this end I shall offer two models of authority, ${ }^{2}$ the hierarchical

1. Notwithstanding the relatively narrow focus of the conventional dichotomy, the rival procedural types springing from it are variously characterized. I have attempted elsewhere to trace diverse ways in which the contrast between adversary and nonadversary procedures can be conceived, and have tried to isolate the opposition most fruitful and illuminating for comparative analysis. This, I believe, is the contrast between the procedural structure of trial as a party contest and as an official inquiry. See Damaska, Evidentiary Barriers to Conviction and Two Models of Criminal Procedure, 121 U. PA. L. REv. 506, 554-78 (1973). The trial-centeredness of the polarization creates many problems, only one of which resides in the fact that the trial is much less crucial a stage in the continental than in the common law system. One cannot deny, however, that the conventional dichotomy possesses an illuminating force, transcending the trial stage of the criminal process. See note 109 infra.

2. See notes 6, 74 infra. As cognoscenti will readily notice, my argument is, in a general way, inspired by a number of Weberian concepts and ideas. Indeed, the hierarchical model is in many respects an effort to adapt Weber's bureaucratic model to the particular problems of criminal procedure. The coordinate model, however, has no simple Weberian analogue. This should not be surprising, given the fact that patterns of authority characteristic of the Anglo-American system seem to elude Weberian typologies. 
and the coordinate, to illuminate respectively the continental and the Anglo-American systems. For heuristic purposes, each model is premised on a very different view of the nature of justice, without any intention to imply that specific conceptions of justice historically precede or causally determine particular patterns of organizing authority.

To many tastes, the development and use of procedural models is an overly abstract scholarly genre. But consider that comparatists are, in a sense, men without a country; their efforts at comprehensiveness, and their separation from the comfortable and the familiar, necessarily invite a reliance upon the abstract. I concede that there are levels of analysis at which procedural models are generally misleading stereotypes or lifeless clichés. They are also simplifications; but this is precisely their default de qualité, indeed their virtue. They are used to liberate us from the tyranny of details, so that we can discern the overall distinguishing attributes of complex phenomena. They will be as useful as our purposes are precise and well-defined. Although my models of authority are mainly provisional markers toward more specific theoretical constructs, I hope to show that even in this crude form they are useful analytic tools, and possibly pedagogical devices.

In an effort to prove the explanatory power of the two models of authority, I have chosen numerous examples. ${ }^{3}$ I do not claim, however, that they were randomly selected and just happen to be consistent with my constructs. Rather, I tried to use as illustrations those features common to actual procedures that are of some interest in themselves. Some, notably those concerning the appellate process, have not been previously elucidated from a comparative standpoint. Others, such as prosecutorial discretion, can easily be misunderstood by commentators, because similar phenomena often subtly change in the radically divergent climate of the two legal cultures. Finally, some

It is needless to dwell here on the controversy over whether there is a meaningful difference between ideal types conceived primarily as heuristic devices and models purporting to describe the most general features of empiric phenomena. On Weber's views concerning ideal types, see M. WEBER, EsSAIS SUR LA THÉORIE DE LA SCIENCE 185 (1966); $R$. Dahrendorf, Class and Crass Conflict in Industrial Society 40 (1959). Even if there is an element of "as-if-ness" about some procedural models, they can still be useful as illuminating metaphors; $c f$. A. Rapoport, Operational Philosophy 203 (1953).

3. I make no claims that variables in the polarization represented by my models were derived in a rigorous methodological fashion. For a perceptive discussion of dangers lurking in the selection of variables, see Abel, $A$ Comparative Theory of Dispute Institutions in Society, 8 LAw \& Soc'y REv. 217, 240-42 (1974). 
illustrations, such as different degrees of bureaucratization on judicial panels, are offered as striking contrasts between the systems.

Since all these areas that I discuss bristle with technical details, many of them Lilliputian and deeply bracketed within local contexts, I must occasionally use a very broad brush; misgivings about some rather robust statements will be allayed in the footnotes. Moreover, for brevity's sake, I shall, whenever possible, appeal to the reader's knowledge in an invitation to rearrange into new configurations what is already known.

\section{The Hierarchical Model}

\section{A. General Characteristics}

\section{The Object of Hierarchy}

The system of values underlying the hierarchical model is characterized by the high premium placed on certainty of decisionmaking. This preference directly affects the tradeoffs with other recognized goals of the criminal justice system, especially the desire to achieve justice in the special circumstances of each individual case. Whenever the consideration of individualized circumstances prevents the conversion of the bases of the particular decision into a general, certain formula, such consideration must be forgone. ${ }^{4}$ If one were to seek a deeper motivation for this great emphasis on certainty, the attitudinal keynote of the hierarchical model would probably be located

4. This, of course, is the logic of the model. In actual continental systems certainty is not inflated to an absolute dogma; there are well-recognized situations in which it must yicld to competing values. The reconsideration of finally adjudicated cases in the interest of justice offers such a counterpoint. It is truc, however, that the continental machincry of criminal justice attributes a significantly greater relative weight to certainty than do some other systems. On this issue, criminal justice mirrors more general characteristics of the continental legal system. See J. Merryman, The Civil Law Tradition 50-58 (1969). Merryman is critical of the continental emphasis on certainty, which he claims is much too abstract. "Like the queen in chess, it can move in any direction." Id. at 50. Note, however, how differently the problem appears in the continental fabric of beliefs. Particularized justice is regarded by a continental lawyer as so elusive and endlessly debatable that he would more readily use the chess metaphor in talking about individualized justice than certainty, which implies the consistent application of a cruder standard. From this perspective it is better to apply across the board a criterion for decision which is just in an average case, than to risk floundering in the sea of particulars; at least one has evenhandedness and uniformity. As we shall see later, the counterassertion of a lawyer in a common law system is that such a position amounts to a quintessentially Procrustean administration of justice. 
in the rationalist desire to impose a relatively simple order on the rich complexities of life.

\section{The Hierarchical Organization}

Certainty in decisionmaking requires that uniform policies be developed. This is indubitably a centripetal striving, leading quite naturally to the centralization of authority. Thus, incumbents of authority positions have no autonomous powers: authority is only delegated to them and its exercise must be closely watched.

This leads to another derivation from the basic orientations of the hierarchical model. Any structure of authority organized along its lines, except the very small ones, is inexorably driven toward rigorous hierarchical ordering. Three attributes of such ordering are important for my purposes. The first is a precise delineation of the province of each official: he must be pinned down to an exact spot determined in relation to the dominant center. Positions of super- and sub-ordination must be sharply defined and unmistakable, almost in a reenactment of the medieval adage "nul homme sans seigneur." All ambiguities in hierarchical relations are viewed as a sorry state of affairs to be quickly remedied; duplicate and overlapping spheres of authority are abhorred. The second attribute of strict ordering is that authority is allocated along a gradient of importance; the higher one climbs the "scalar" of hierarchy, the more comprehensive and important the authority one acquires. Put differently, there is a pronounced inequality among officials on various hierarchical echelons, especially in terms of the kinds of questions delegated to each for decision. The third attribute concerns the interrelationship of officials at the same level, and leads to the separation of office and incumbent: Where an individual official is delegated authority to make a decision, the decision can be changed only by hierarchical superiors. Thus it is binding on all coequal officials, and becomes a decision of an administrative unit. On the other hand, where a decision is collective, it must express the will of the group as a readily identifiable object of superior review. The group is transmogrified into an institution which assumes a life of its own, distinct and apart from the individuals comprising it.

The more freedom officials retain, the more difficult it becomes to achieve certainty and uniformity of decisionmaking. Accordingly, the hierarchical model strives to guide its officials by outcome-determining normative propositions in as many situations as can be 
anticipated. The more precise the directives contained in these propositions, the better. Directives must be sufficiently rigid that they cannot be altered or evaded when officials applying them feel they lead to undesirable outcomes. To remedy such regrettable situations is not the business of officials in the hierarchical model. Yet the desire for precision and comprehensiveness of normative propositions creates a difficulty: Precise directives covering wide areas of experience can easily conflict. Hence there are strong demands in the hierarchical model for the ordering, systematization and simplification of the normative universe.

What emerges from this brief description is that the use of "official discretion" is viewed with disfavor. ${ }^{5}$ Essentially, the exercise of discretion represents a necessary evil in the hierarchical model, an evil to be tolerated so long as more precise guidelines for official action cannot be formulated.

Intimately linked to the "brooding omnipresence" of hierarchical review is the great importance attached to official documentation and bureaucratic techniques. All official decisions must be recorded and traces of all other official activity preserved for possible supervision by higher officials. To facilitate the work of the latter, standardization and formalization of official documents and reports are demanded.

The foregoing features of the hierarchical model influence officials' perceptions of their roles. Consider, for instance, the ideal of official decisionmaking: This process is one in which clear directives are applied to accurately determined facts. The personal views of officials as to the desirability of the outcome of this process must be considered irrelevant. Officials are "servants," members of the service class merely administering normative standards which are supplied to them. If they were permitted to question these standards and depart from them when they deemed it appropriate, the very foundation of the hierarchical model would be shaken; the certainty and predictability of official decisions would be endangered. Since few areas are free from normative intrusion, and since the systematic organiza-

5. Because of the relatively recent debate in Anglo-American legal theory concerning the meaning of discretion, a definitional remark is in order here. As used in this essay the term is not limited to situations of full official freedom from the application of normative standards. It is intended also to cover those situations in which an official is guided by vague standards, making predictability difficult. Compare Dworkin, The Model of Rules, 35 U. ChI. L. Rev. 14, 32-40 (1967), with A. DE LaUbadEke, Traité de Droit AdMINISTRATIF 261-62 (6th ed. 1973) (discussing the French concept of pouvoir discrétionnaire).

Of course, "discretion" appears differently when, rather than used as a point of contrast between systems, its uses (and the shortcomings of those uses) are examined within a single system. See Rosett, Discretion, Severity and Legality in Criminal Justice, $46 \mathrm{~S}$. CAL. L. REV. 12 (1972). 
tion of normative criteria achieves a degree of insulation from external considerations, the problems involved in decisionmaking appear essentially as nonpolitical, technical tasks.

What are the most important qualifications for a position in the official hierarchy? An office holder must be a technical expert capable of efficiently applying normative standards, irrespective of what interests are thereby served. A good official is also one who has mastered the bureaucratic skills that permit the smooth functioning of the hierarchical authority structure. Generating bureaucratic minutiae is not regarded as an irksome chore, preventing an office holder from performing more important tasks. Rather, the deft handling of files and similar bureaucratic techniques are accepted as essential skills of proficient officials.

Role expectations are reinforced by a variety of mechanisms within the hierarchical model. Prominent among these mechanisms are the training for official positions, recruitment techniques, and the system of promotions. Entry into a strictly ordered officialdom begins at the lowest rung of the hierarchical ladder. Established people will seldom be willing to begin at the bottom, and thus an entrant will typically be a technically skilled young man who has undergone both systematic instruction in the normative system and practical training in bureaucratic techniques. His aptitude may be tested by entrance examinations. Because there is practically no lateral entry to higher positions, important officials will be those who have ascended the ladder of hierarchy through periodic promotions which depend, at least to some extent, on performance evaluations by one's superiors.

To this cursory sketch of the hierarchical model a few reflections must be added by way of transition from the description of the model to its comparison with actual continental systems. ${ }^{\circ}$ Of course,

6. The proximity of the hierarchical model to a number of Weberian ideas is obvious. The aspirations of the model may be viewed as premises underlying the "logically formal rationality" of legal thought as understood by Weber. The organization of the model incorporates, both explicitly and by implication, many constituent elements of the "bureaucratic" (or "legal") type of domination (Herrschaft). See Max Weber on Economy and Society xxxi-xxxiv (M. Rheinstein ed. 1954). The most important deviation of the hierarchical model from Weber's bureaucratic authority is the absence in the former of the impersonal, detached style of exercising authority. The comparison of modern continental and Anglo-American system on this score is exceedingly complex and of uncertain outcome. See note 74 infra.

I have neglected to emphasize the impersonality of orders within the hierarchy, for I believe that in all bureaucracies a strong feeling of personal dependence remains. Many will claim that Weber believed that the structure of power determines legal order rather than vice versa. Because I sketch the hierarchical model as originating in the quest for certainty and order, I may be interpreted as implying that certain value orientations precede patterns of authority. I make no such claims. See note 158 infra. For a thoughtful and very lucid recent discussion of the relationship between political structure and legal thinking in Weber's work, see Trubek, Max Weber on Law and the Rise of Capitalism, 1972 WIS. L. REV. 720, 731-35. 
discrepancies will exist between the demands of the hierarchical model and the reality of systems which it approximates.

For example, with respect to official decisionmaking, one cannot seriously expect that an authority structure can be devised in which normative propositions completely determine the outcome of decisions. The latter can seldom be complete and inexorable derivations from normative standards. But even if the ideal of decisionmaking in the hierarchical model were both logically and psychologically an impossibility, this hardly implies that decisionmaking is independent of variations in the structure of authority or that the folklore developed by such structures can be relegated to the realm of myths having no operational significance. Indeed, the relative weight of the normative variable in the equation of factors determining the actual official decision seems to change significantly from one type of authority structure to another.

\section{B. The Hierarchical Model and Continental Reality}

At first the scene on the Continent seems too vast and complex to handle. Important variations can be observed from country to country, and many factors of diverse origin pull actual systems of criminal justice away from the hierarchical model to a degree one cannot easily determine. Nonetheless, a general continental pattern can be discerned from these features: the strong tendency to arrive at uniform policies through the centralization of authority; the rigorously hierarchical ordering of agencies participating in the administration of justice; the preference for precise and rigid normative directives over more flexible standards; and, finally, the great importance accorded official documentation. This general, bureaucratic style of exercising authority tends to be sustained everywhere by chosen methods of training, recruiting and promoting officials. It is around these foci that my presentation will revolve.

\section{Centripetal Decisionmaking}

a. Police Forces and Public Prosecutors. It is commonplace that centralization of both the police and the prosecutorial corps remains the dominant structural principle of all continental systems. ${ }^{7}$ Central

7. Continental police forces are usually subordinate to the Minister of the Interior. In some countries, there are police forces with no organizational unity. Thus, for instance, some systems assign a segment of the police force to the Ministry of Justice, and it is only this segment which is entitled to participate in the criminal process. The rest of the 
authorities issue binding general directives to local officials and can give specific instructions on the handling of a particular case. ${ }^{\$}$ Even where, sporadically, a degree of local independence is cultivated, local police and prosecutors are far from being important local potentates. Although the federal system of some continental countries may occasionally lead to the absence of organizational unity on the national level, strong forces are at work to coordinate law enforcement among federal units and establish uniform national policies. ${ }^{9}$

b. The Judiciary. Turning to the continental judiciary, the picture becomes much more complex because of cross-currents and offsetting tendencies. I shall first consider those characteristics of the judicial organization that accord with the hierarchical model, and that deal with features that seem to deviate from it.

There are in the continental judicial systems ${ }^{10}$ two decisive weap-

police remain under the Ministry of the Interior. This is, essentially, the French pattern of division between the "judicial" (law enforcement) and "administrative" (peacekeeping) branches of the police force. See G. Stefani \& G. Levasseur, Procédure PÉNale 347-68 (2d ed. 1962). Even in this case, however, police forces are ultimately responsible to an important member of the central government. Attempts have been made to transplant a decentralized pattern of police organization to countries with a different tradition; most of these experiments, however, have failed. See, e.g., Nakahara, The Japanese Police, 46 J. Crim. L.C. \& P.S. 583 (1955) (Japanese experience with American ideas).

Continental offices of public prosecution are strictly centralized. For the French Ministère Public, see G. Strfani \& G. Levassevr, supra, at 460 . True, there is the oft-proclaimed freedom of the French prosecutor to deviate from directives of his superiors in his oral arguments in court; but this folkloric proclamation has been termed "a joke" in its practical effects. See VILLÉRÉ, L'AFFAIRE DE LA SECTION SPECIALE 270 (1973). For the West German system, see Jescheck, The Discretionary Powers of the Prosecuting Attorney in West Germany, 18 AM. J. CoMP. L. 508, 511 (1970). On the Russian prosecutor, see H. Berman, Soviet Criminal LAw and Procedure 109-17 (1966). Relatively speaking, Dutch prosecutors have a degree of local independence. See Rosett, Trial and Discretion in Dutch Criminal Justice, 19 U.C.L.A. L. REv. 353, 364.65 (1972).

8. On the limits of this subordination see Jescheck, supra note 7, at 511 . See generally Vouin, The Role of the Prosecutor in French Criminal Trials, 18 AM. J. CoMp. L. 483, 487.89 (1970).

9. This is, for example, the case in West Germany, where the police and prosecutorial offices are organized on the state, not federal, level. But a striving for uniformity is nevertheless obvious. See Richtlinien für das Strafuerfahren, in STRAFrRozessordnung (T. Kleinknecht ed. 30th ed. 1972). In this connection it must also be noted that, for the sake of uniformity, both substantive and procedural criminal law tends to be heavily "federalized" in all continental federations. The Soviet Union is only an apparent exception, because the constituent republics are bound by federal model legislation in both procedure and substance. Swiss cantons in the field of procedure, and the Yugoslav constituent republics in substantive law, can more properly be viewed as minor deviations from the prevailing continental pattern of "treating" criminal law essentially as a federal matter.

10. In federally structured continental countries there are no parallel hierarchies of federal and state courts. The only federal court is the supreme court, placed at the apex of the national hierarchy of regular courts. In case of a conflict between state supreme courts and the federal supreme court, various mechanisms exist for bringing the issue to the latter for resolution. For an example in West Germany, see E. KerN, STRAfverfahrensRECHT 32 (8th ed. 1967).

Outside the area of our interest, i.e., courts of general jurisdiction which consider criminal cases, the prevailing continental pattern displays a multiplicity of independent judicial hierarchies. Rather than a unified court system for the whole country with a single supreme court, there will be special commercial and administrative courts, perhaps 
ons to cope with centrifugal tendencies in administering criminal justice. One is the comprehensive and widely used system of appeals; the other, the comparatively weak forms of lay participation in adjudication.

The comprehensive system of appellate review has a long record on the Continent. Those wishing to trace its history must venture deep into the hidden origins of the modern state, when continental rulers began to build bureaucracies to establish their control over previously independent provincial and local authorities. ${ }^{11}$ As befits a system in

even a special constitutional court. The historical reason for this deviation from the ideal of rigid centralization originate in attitudes very close to what I have described, in the administration of criminal justice, as the attitudinal keynote of the hierarchical model. Yet it would be a serious mistake to believe that this multiplicity of hierarchies, with the unavoidable conflicts arising therefrom, seriously affects the unity of the legal system in continental countries; everywhere mechanisms have been developed to settle interhierarchy conflicts. See R. Schlesinger, Comparative Law 350 (3d ed. 1970).

11. The origin of the appellate system in Western civilization is usually traced back to the post-classical Roman idea that judges exercise their authority by delegation from the emperor. See T. Mommsen, Römisches Strafrechr 980 (1899). Appellate review was, however, alien to early medieval society; it is fair to say that appeal was "reinvented" after 1100 A.D. when institutions of the modern state began slowly to emerge.

This movement began in connection with the centralization within the Roman Catholic church, as a network of ecclessiastical courts developed with the Pope as judex ordinarius omnium. Soon afterward, accompanying royal centralization, the appellate process bccame firmly entrenched in the French legal system. Under the famous Criminal Ordinance of Louis XIV (1670), and probably even before, an appeal was automatic in many criminal cases. See A. Esmein, Histoire de la Procédure Criminelle en France 177-283 (1882). Italian medieval lawyers who struck the foundation of continental $j u s$ commune main. tained that an appeal must be permitted both from interlocutory decisions (e.g., a decision to extract a confession by torture) and from final determination of the trial court. Many authorities claimed that custom or statutes could not abolish appeals in criminal matters. See, e.g., 2 Consilia et Singularia OMnia Domini Hippolyti de MarsiLIIS, Consilium 84, at 11 (1537) [hereinafter cited as DE MARsiLis]. The judge who refused to transmit an appeal to the superior court was liable to punishment. See the opinion of Angelus Aretinus de Gambilionibus, in 2 Salvioli, Storia della Procedura Civile $e$ Criminale in 3 Storia DeL Diritro Italiano (P. del Giudice ed. 1927).

Nor was the defendant the only one permitted to appeal; various representatives of fiscal interest were entitled to appeal from acquittals. See Salvioli, supra. However, Italian practice in inquisitorial proceedings imposed serious limitations on the defendant's right to appeal, and in some city-states appeals virtually fell into desuetude. Later theory hedged the right to appeal in criminal matters with numerous exceptions, some of which had been advocated even earlier. See 1 DE MArsilis, Consilium I, at 1, for crimina lese maiestatis. Among the reasons advanced by scholars for these developments were the sufficient guarantees against error supplied and the nefarious maxim propter enormitatem delicti licitum est iura transgredi (laws may be disregarded because of the magnitude of crime). See 1 DE MarsiliIs, Consilium 5, at 9. These Italian ideas were picked up by the 17 th century German authority, Benedict Carpzov, and through his influence adopted in the continental inquisitorial proceedings of many countries. See B. CARPzov, Practica Nova RERUM CRIMINAlium IMPERIalis saxonica, Pars 3, Questio 139, no. 14 (1739). This does not mean, however, that in German countries there was no review of judicial decisions in criminal matters. Some interlocutory decisions remained appealable (e.g., the decision to torture the defendant). Also the investigator's file would be transmitted to a panel of "legal experts" for decision, and the decision of the latter-at least in capital cases-reconsidered by a competent ministry.

Carpzov's ideas did not remain unchallenged by his contemporaries. See R. StINTzING, GESCHICHTE DER DEUTSCHEN RECHTSWISSENSCHAFT 101 (1884). At any rate, appellate review, already quite refined in civil matters, was again widely permitted in criminal cases in the early 19th century. See Fiorelli, Appello (Diritto Intermedio), in 2 ENciclopedia DEL Diritro 714 (1958). 
which decisions of subordinates are supervised by those closer to the center of power, appellate review was from its inception conceived as a comprehensive device that permitted, at least at the first level of review, a complete reconsideration of the case. Thus criminal appeal in all modern continental systems implies a review not only of alleged legal error, but also of factual findings and even the punishment imposed. ${ }^{12}$ Nor is it surprising, in light of centuries of tradition, that appellate review gradually became associated with fairness in the administration of justice. Indeed, in modern continental countries, the "right of appeal" is usually elevated to the constitutional level. The appellate process is made very inexpensive, and is not risky for the parties. ${ }^{13}$ In large classes of criminal cases even supreme courts can be reached as a matter of right through the mechanism of appeals. Of course, one consequence of this is that supreme courts lose control over their dockets and must handle a large volume of business. Relatively large numbers of judges must be appointed to the top of the judicial hierarchy and divided into panels, some of which specialize in the adjudication of criminal cases. ${ }^{14}$ But the uncertainty produced while waiting for the Supreme Court to consent to decide a controversial question is almost totally absent from the continental scene, and the continental appellate mechanism is able to achieve considerable uniformity of decisionmaking on most of the important issues arising in the administration of criminal justice.

The ready availability of appellate review has bequeathed many legacies to all continental procedures. One of these must be pursued in some detail, because, as I shall later show, it explains so many

12. For simplicity's sake $I$ apply the term "appeal" to all ordinary legal remedies. See note 15 infra. In some, but not all, continental systems, after the intermediate appellate court has spoken, further appeal is permitted only on matters of law. Sentencing problems may raise isstues of "illegality" and "inappropriateness." See Miueller \& LePoole, Appellate Review of Legal but Excessive Sentences: A Comparative Study, 21 VAND. L. REv. 411, 418 (1968).

13. The elimination of risk is connected with the generally accepted principle prohibiting reformatio in peius, i.e., preventing the appellate court from using the defendant's appeal as an opportunity to modify the judgment of the court below to the detriment of the appellant. In most continental jurisdictions, the ban applies to proceedings on retrial as well; but the limits of the prohibition in this situation differ from country to country and are uncertain and controversial.

14. For instance the criminal law division ( $L a$ Chambre criminelle) of the French Supreme Court (Cour de cassation) consists of one president, seventeen judges, and, of late, four judicial assistants (conseillers référendaires). Inconsistencies among supreme court panels can and do arise. But various mandatory devices have been developed in all jurisdictions to assure the unity of decisionmaking. For instance, a panel is not authorized simply to deviate from a prior decision of another panel, and must submit the issue to a larger body within the supreme court for resolution. Although the continental legal folklore maintains that judges are not formally bound by prior decisions-in the interest of uniformity of decisionmaking-this supposed rule does not apply to judges at the supreme court level. Paradoxically, they seem to have less potential freedom of action than lower judges. 
puzzling technical contrasts between Anglo-American and continental procedural arrangements.

Where judicial decisions are normally subject to reconsideration, it is quite natural to postpone their finality and execution until the ordinary means of review have been exhausted.15 In this situation, however, the appellate process becomes a continuation of trial adjudication. Consider the immediate impact of this development on notions of double jeopardy: ${ }^{16}$ If an appeal is part and parcel of one single proceeding, jeopardy must be regarded as continuing until the termination of the entire criminal case. Thus, an appeal by the prosecution from an acquittal would not violate the prohibition against double jeopardy. Similarly, because convictions are also not final, it is unnecessary to explain the permissibility of a defendant's appeal by constructs such as waiver of jeopardy or other fictions. Moreover, the defendant need not seek a stay of execution; the execution of judgments is automatically postponed, at least until the time limit for the filing of an appeal has expired.

But here I have, perhaps, already gone too far into technical detail. Let me, therefore, quickly turn to the other centripetal weapon at the disposal of the continental judicial system.

A pure hierarchical model regards with great misgivings any participation of lay people in the administration of justice. The reasons for this attitude are not difficult to see: Laymen are usually unable and often unwilling to look at criminal cases through the prism of general rules. To laymen each case is a crisis, a unique human drama, rather than a representative of a general class. Thus, no matter what form it takes, lay participation always injects an element of unpredictability into the criminal justice system.

There are, however, important differences in the degree to which lay participation in adjudication conflicts with the hierarchical model. At one pole, and fundamentally antagonistic to the model, is the Anglo-American jury trial. Decentralized administration is inevitable where lay people are expected to apply local standards in determining guilt, and are even permitted to set aside the centrally imposed criminal law embodied in the judge's instructions. Furthermore, the largely inscrutable and often unchallengeable general verdict rep-

15. Medieval continental law had already elaborated a distinction between ordinary legal remedies which suspend the res judicata effect of decisions and extraordinary legal remedies to be used in exceptional situations after the judgment had become legally binding and executable. It is often mistakenly assumed that this distinction corresponds to that of direct and collateral attack in American law.

16. The continental counterpart to the prohibition against double jeopardy is the ne bis in idem maxim. 
resents a crowning example of autonomous rather than delegated adjudicative powers.

At the other extreme, from the later Middle Ages to the French Revolution, the administration of justice on the Continent was dominated by professional adjudicators. Revolutionary times inaugurated a change. It was a period permeated by a somewhat naive intoxication with the exotic but never fully understood charm of English political institutions. It was also an epoch of great distrust of the politically reactionary judicial bureaucracy. The two circumstances in combination explain the curious phenomenon that, in the wake of the victorious French Revolution, the jury trial was transferred to the Continent, although the English ways of organizing society were quite alien to French revolutionary ideology. ${ }^{17}$ It is important to note, however, that the broad jury discretion was not imported; from the very beginning, professional officials retained more control over the jury than was the case in England. ${ }^{18}$ More importantly the transplanted jury, even in this adulterated form, never really became acculturated on the Continent. Without recounting here the exquisite misadventures of the continental jury, ${ }^{19}$ suffice it to note that the jury soon suffered a decline in all European countries. Nevertheless, though somewhat distorted in the transforming screen of all ideological migrations, the idea of lay participation in the adjudication of criminal cases remained a potent political force. Because the judicial bureaucracy was never powerful enough to secure a complete reversion to professional adjudication in criminal matters, the natural result, a sort of compromise, was the adoption of a milder form of lay participation. The prevailing form came to be a mixed bench on

17. Consider only the extent to which the English jury as an autonomous decisionmaker actually conflicts with the revolutionary ideal of a judge who mechanically applies preexisting legislative norms. This is, of course, Montesquieu's idea of the adjudicator as la bouche de la loi.

18. The general verdict was rejected in favor of a form of special verdict, and the unanimity of jurors was never required. Although briefly, during Year $V$, the jury verdict was supposed to be unanimous, if unanimity could not be achieved within 24 hours, a simple majority would suffice. There was also a limited possibility of changing the jury verdict by adding new jurors if, in the unanimous opinion of professional judges, the existing jurors committed a mistake. Probably the best account of the original revolutionary jury is still A. EsmeIN, supra note 11, at 417-30. In addition, from the beginning the possibility existed of proceedings in absentia. Jury trials could not be "waived" by the defendant; even if he "pleaded guilty," the case would still have to go to the jury. The significance of these two deviations from the English model will be discussed later in connection with the ideological basis of the Anglo-American system.

19. For an excellent account, see Mannheim, Trial by Jury in Modern Continental Criminal Law, 53 LAw Q. REv. 99, 388 (1937). Even the French have since abolished the jury as an independent decisionmaker. The 1941 reforms of the Vichy government, never repealed on this point by postwar legislation, created a system in which the jurors deliberate and vote jointly with professional judges. Somewhat special is the history of the Tsarist Russian jury introduced in 1864 and abolished by the Soviet government. See S. Kucherov, Courts, Lawyers and Trials under the Last Three Tsars 51-86 (1953). 
which professional and lay judges sat and decided jointly, and this is still the representative continental adjudicative body in criminal matters. ${ }^{20}$

It would be an exaggeration to claim that the actual significance of lay assessors reduces everywhere to a mere nonfunctional political embellishment of the decisional body. But few would deny that the professional judge on the mixed bench is such a towering figure that the lay influence is rather negligible, ${ }^{21}$ and nowhere does this influence seriously impede uniformity and predictability of decisionmaking. Moreover, an appeal lies from the mixed bench to higher courts which review the entire record, and these courts are typically composed solely of professional judges.

While it appears that all continental systems have evolved potent mechanisms to counteract centrifugal tendencies in the administration of criminal justice, a balanced appraisal must recognize departures from the ideal of strict judicial centralization. Some of these departures are simply the minimal requirements of judicial independence in all modern legal systems. But one centrifugal feature of a different sort is significant for comparative purposes.

In a centralized judicial system which sets great store by consistency of decisionmaking, one would expect to find a policy that requires judges to abide by normative standards expressed by their superiors. Strangely enough, no such policy is espoused by continental systems, at least as a matter of formal legal doctrine. Is this phenomenon, in its actual impact, a serious departure from the ideal of judicial centralization? Not quite. But to understand the development of this phenomenon one must first turn to the seemingly inapposite continental doctrine against judicial lawmaking.

One obvious source of this doctrine is the ideology which inspired the French Revolution; like most revolutionary thought, it was not

20. There are, of course, many varieties in the composition of the mixed tribunal. By way of exception, adjudication by professional judges existed solely in prewar Yugoslavia and still persists only in Holland.

21. This rather general impression has recently been substantiated by empirical research. See, e.g., Casper \& Zeisel, Lay Judges in the German Criminal Courts, 1 J. Legat STUDIEs 135, 186 (1972); Zawadzky Kubicki, L'elément populaire et le juge professionel dans la procédure pénale en Pologne, 50 Revue de Droir Pénal et de Criminologie 919, 929 (1970).

$A$ recent Soviet study revealed that disagreements between the professional judge and lay-assessors in trial courts arise in only 18 percent of cases surveyed. Of these, only one percent involved disagreement over the guilt of the defendant. The overwhelming majority of disagreements concerned the magnitude of punishment. Indeed, sentencing is regarded by many lay-assessors as the main purpose of the criminal trial. See Raditnaya, $O$ metodike issledovanya effektivnosti uchastiya narodnih zasedatelei $v$ osushcestvenii pravosudia, in EFFEKTIVNoST PRIMENENIYA UgolovNogo zAKoNA 195-97 (N. Kuznetsova \& I. Mikhaylovskaya eds. 1973). 
without a utopian element. It was predicated on the assumption that normative standards could be developed with such clarity and over so broad a range of issues that their application to individual cases would require no creative activity on the part of the judge. This restrictive role was regarded as a postulate of national legal unity and as a means of furthering legal certainty. These two values called for judicial centralization, which, after a brief interlude, became one of the important achievements of the Revolution. ${ }^{22}$

Since the proper business of the judiciary was to be solely the application of norms, rather than their formulation, judicial centralization was conceived exclusively as centralization of application. Not even the highest court could authoritatively decide the meaning of legal propositions..$^{23}$ Even on appeal, traditionally so important, review was to involve only the propriety of the process of norm application, imagined syllogistically. True, the higher court could disagree with the court below on the meaning of the normative standard for de-

22. Pre-revolutionary French courts (Parlements) were a centrifugal force, opposed to the unification of the law. Parlements had the authority to render decisions, not necessarily in the context of an actual litigation, enunciating legal views to be applied in future cases (arrêts de réglement). In the 18th century, conflicts between these courts and the monarchy were quite frequent, occasionally creating scandals.

Le règne de Louis XV, jusqu'en 1770 , fut fertils en conflits entre [Parlements] et le pouvoir royale, ... et les deux partis allaient jusqu'a l'êxtreme usage de leurs droits traditionels.

A. Esmein, Cours fleméntaire D'Histoire Du Droit Francais 520 (1921); J. Shennan, The Parlement in the Eighteenth Century, The Parlement of Paris 285 (I968). In addition, conflicts among the 14 Parlements on many legal issues often occurred during the Ancien Règime. In contrast to common law judges, the French judiciary was not so definitely on the side of the middle class, in many respects judges were quite reactionary, and French revolutionary ideology was strongly antijudicial. This ideology reached countries with quite different judicial traditions. See note 26 infra.

23. Analytically this determination can take place in three situations. The first is one in which the supreme court determines general rules independently of actual litigation. This is pure judicial legislation. Another is by a determination for the case sub judice, i.e., by a legal opinion expressed in remanding to the court below. Finally, legal opinions expressed by the supreme court in actual litigation may be considered binding in another similar case. The original revolutionary ideology prohibited supreme courts trom making binding determination in all of these situations. M. CAPPELLETI, J. MIERRYMAN \& J. Perillo, The Italian Legal System 150 (1967).

The very process of judicial interpretation, be it authoritative or not, was viewed with suspicion in the revolutionary eras. Thus, more than a century before the French revolution, English Levellers advocated a simple codification of law, coupled with a ban on judicial interpretation. See Shapiro, Codification of the Laws in Seventeenth Century England, 1974 Wis. L. REv. 428, 449-50, 455. Two French revolutionary decrees of 1790 forbade courts any interpretation of laws. See F. NeumanN, The Democratic ANd THE AUTHORITARIAN STATE 38, 141 (1957).

Less known is the fact that this radical ideology of the rising bourgeoisie was shared by continental "enlightened monarchs" in their efforts to codify the law. For instance, on April 14, 1780, a decade before the aforementioned French revolutionary decrees, Frederich II of Prussia prohibited judicial interpretation of laws. Similarly, in 1786, Emperor Joseph II of Austria prohibited interpretation of his Code. An instruction was passed in Bavaria in 1813 forbidding the writing of commentaries to the famous Bavarian Penal Code of the same year. See id. This alliance of monarchical and bourgeois interests in shaping the law on the Continent is a major theme in Max Weber's work. See Max WEBER ON LAW IN ECONOMY AND SocieTY 267, 279, 289 (M. Rheinstein ed. 1954). 
cision, but it could not require adherence to its views even in remanding a case for retrial. ${ }^{24}$ Given the internal logic of the doctrine this is not a strange arrangement. If the creation of law is ultra vires for the judiciary, there cannot be any super- or sub-ordination on this issue. All judges are equally subordinated to the legislator. The strength of their legal pronouncement derives solely from supporting arguments. Tantum valet quantum ratio probat. ${ }^{25}$

As revolutionary ideology confronted the constraints of the possible, the pristine views on the role of the judge were qualified somewhat. Nevertheless, the basic contours of the doctrine remain intact to the present day and its continuing vitality can be seen as an ideal to be approximated. ${ }^{26}$ Those inroads that have been made are in the narrow area of binding lower courts to legal views expressed by superiors on the remand of a case for reconsideration. ${ }^{27}$

So much then for continental legal folklore. More relevant to my purposes is the actual importance of normative standards expressed by superior courts for the decisionmaking of courts below.

Although technically not binding, these normative standards are of extreme importance in the actual operation of criminal justice. ${ }^{28}$ Because the striving for uniformity and consistent decisionmaking

24. See note 27 infra.

25. "It is worth as much as can be proven by reason."

26. This attitude toward judicial legislation can no longer be attributed either to the traumatic experience with French judges during the Ancien Régime or to the relatively rigid continental views on separation of powers. A deeper explanation focuses on the continental belief that judicial lawmaking (unless guided by scholarly conceptual frameworks or legislative directives) results in casuistry, ultimately subverting legal certainty. This belief probably dates back to the rise of medieval universities; praxis caecus in via is an adage much older than Montesquiet. But this problem is a faded fresco I cannot even begin to restore here. For a modern reconstruction of this doctrine, see the decision of the West German Constitutional Court cited infra note 69.

27. In some continental countries the legal rulc determined by the supreme court is binding on first remand. In the majority of jurisdictions, however, the old doctrine is partially maintained, and the first court of remand retains the option to refuse to apply the law as entuciated by the supreme court. Only if a larger augmented panel meets (e.g., a supreme court session) following a second appeal will its legal view be binding on second remand. At the level of the intermediate appellate courts, the old doctrine frequently preserves its full force.

It is true that in some systems repeated decisions of supreme courts are legally binding (jurisprudence constante, doctrina legal), but this is usually explained in terms of custom. Decisions of constitutional courts are also legally binding, but these courts are sui generis.

Sophisticated continental theorists seem of late to recognize some additional instances in which court decisions possess legally (not factually) binding power. Most interesting of these is the case in which a supreme court announces an important legal principle (e.g., that mistake of law constitutes a defense, or that debts should be revalued due to currency collapse), and this principle accords with widely held convictions of justice. See K. LARENZ, MethodenLehre DER ReCHTSWISSENSChAFT 411 (2d ed. 1969).

28. On this subject the literature is truly vast. For a subtle and insightful presentation, see R. Schlesinger, supra note 10, at 434; cf. J. Merryman, supra note 5, at 23, 48. Unless conformity were expected, such formal opinions would be nonsensical. 
is such an overriding tendency in all continental systems, a number of mechanisms have been designed to make lower courts accept legal propositions developed by superior courts.

Such mechanisms may operate outside actual litigation. In many countries, for example, supreme courts will formally enunciate advisory legal opinions; although usually not binding, these opinions in actual fact will be followed. ${ }^{29}$ Less visible, never published, but perhaps more important are various internal recommendations and circulars on legal issues flowing from higher to lower courts on diverse occasions, such as following the inspection of lower courts or perusal of their files.

Closer to the enunciation of normative propositions in actual litigation, and appearing quite bizarre to outsiders, are the "audit" procedures by which supreme courts review final decisions "in the interest of the law." 30 Frequently their effect is solely to declare that in a decision "law was misinterpreted," but without changing the adjudication. The effet platonique of such supreme court decisions remains entirely incomprehensible unless their purpose is revealed as one of assuring uniformity of decisionmaking in lower courts. Finally, the pervasive appellate mechanism renders legal opinions of higher courts quite important. If the lower court judge fails to follow the legal views of his superiors, his decision inevitably will either be reversed or amended. All continental systems, mirroring the hierarchical model, have developed effective pressures against the display of obstinacy and independent assertion of views by the lower judiciary. Briefly, when the continental judge knows of a legal view expressed by his superiors and has reason to believe they still adhere to it, he will usually follow it even without any doctrinal obligation

29. Occasionally such opinions are even declared legally binding. An interesting example was the system adopted by the Tsarist Russian supreme court (Ruling Senate). Its rulings, if rendered by "super-panels" (an enlarged complement of judges), were binding on similar cases in the future. See N. ROzIN, UCOLOVNOE SudorroizVodsTro 85 (1916). Of course, Russian legal scholars of the time, steeped in the continental legal tradition, tried desperately to reconcile this judicial legislation with the prevailing legal folklore. In a modern reflection of the old system, Soviet supreme courts can presently also issue binding directives to courts below (so-called postanovlenia), and their example is followed in some Eastern European systems. But, in keeping with the orthodox continental theory of legal sources, this actual norm-creating activity is classified as one pertaining solely to the "application" of law, a supposedly automatic operation devoid of judicial creativity. See 1 M. Strogovich, Kurs Sovetskogo Ugolovnogo Protsessa 73-74 (1968). Sovict legal theory is generally hostile to judicial legislation, which it associates with law in monopolist capitalism. See V. Tumanov, Burzhuaznala Pravovala Ideologila 74 (1971).

30. A prototype of such a mechanism is the French "pourvoi en cassation dans l'intérêt de la loi." See G. STEFAn \& G. Levasseur, supra note 7, at 757-59. Similar devices cxist in Austria (arts. 33 and 282, Code of Penal Procedurc), and in most Eastern European countries. See Rudzinski, Soviet-Type Audit Proceedings and their IFestern Counterparts, in L. Boim, G. Morgan \& A. Rudzinski, Legal Controls in the Soviet Union 287 (1966). 
to do so. Whether this view happens to be expressed within or without the context of a particular case will be largely irrelevant to him. Instances in which trial judges actually use the freedom to develop legal standards accorded them by the system's folklore constitute quite rare deviations from the mode.

This does not mean, however, that continental systems have adopted in practice, although not in theory, the doctrine of stare decisis. ${ }^{31}$ As already shown, prior decisions rendered in actual litigation have serious competitors as sources of information on legal views of higher courts. $^{32}$ But even if the first reaction of continental judges were always to reach for prior decisions, an important difference would still remain between their style and that expressed by the doctrine of stare decisis. To a continental judge a prior decision is not a "case," a solution to a real life problem in all the richness of its raw facts. What he is looking for in a decision is essentially a specification of a more general legal proposition that will cover the case before him. The facts of the decided case will seldom interest him; indeed, they may often constitute a regrettable distraction from his proper business of finding a precisely articulated standard. ${ }^{33}$ Most of the time, an abstract legal proposition, totally denuded of the enveloping factual context, will suffice for his purposes. Gone is the flexibility springing from the "distinguishing" of cases on their facts, or emanating from broader and narrower formulation of holdings. Gone also is the freedom resulting from the various degrees of weight that can be attri-

31. It is sometimes said that, at the time of the French Revolution, continental countries rejected stare decisis, while importing many other English judicial institutions. In fact, they were only reacting to their own pre-revolutionary experience. The doctrine of stare decisis is a product of the 19th century, and did not even exist in England at the time when French political theorists looked to that country for inspiration. The necessary cohesion of the English common law was maintained at the time by the oral transmission of tradition within a small group of lawyers and judges. The stare decisis doctrine appeared only after the expansion of the judicial system broke down the cohesion of the common law. See A. Simpson, The Common LAw and Legal Theory, in Oxford Essays In Jurisprudence (Second Series) 77, 98 (1973). Assume, however, that French revolutionists were familiar with an analogue of stare decisis, conceived as an instrument designed to assure consistency in a system where law gradually evolves from judicial decisionmaking; even so, they would have rejected such doctrine without hesitancy because it clashes irreconcilably with the view that legal standards must be formulated by the legislator rather than the judiciary.

$A$ related but unexplored contemporary question concerns the effect of an accelerated pace of change on the doctrine of stare decisis, the essence of which is tradition.

32. An important additional source of information are commentaries written by scholars whose primary function is to maintain order in the normative universe.

33. Therefore, continental decisions will contain only the thinnest distillate of legally relevant facts. Building upon an idea expressed by T.S. Kuhn, one would say that continentals do not treat prior cases as examples shared by the profession, examples that are applied without mediation of rules. Rather from the examples (actual decided cases) they abstract rules which are to function instead of shared examples. The two processes are altogether different manners of knowing. T. KuHN, THE Structure of Scientific Revolu. TION 192 (2d ed. 1970). 
buted to precedents. The rule found in the decision either applies or it does not. ${ }^{34}$ This difference is of great importance, because following prior decisions in the continental fashion leads to much more rigidity than is the case under the stare decisis doctrine. While the latter does not prevent the growth of law, the former easily can. ${ }^{35}$

Here I must return from my excursion into deviations by the continental judicial organization from the ideal of strict centralization. These deviations do not prevent the machinery of justice from maintaining a high degree of uniformity in decisionmaking, and strong pressure toward centralization remains one of the most distinguishing characteristics of all continental agencies operating in the administration of criminal justice.

\section{Rigid Ordering of Authority}

Preceding by several centuries the unification of law, stratified administrative structures appeared on the Continent as early as the 13th century. ${ }^{36}$ In discussing the elaborate appellate system that resulted from this development, I have already touched on some hierarchical aspects. What remains for consideration are three characteristics of a rigorous hierarchical design suggested by the hierarchical model. As the highly defined stratification of continental police and public prosecution is too plain for argument, I shall focus solely on the organization of the judiciary.

The first characteristic is the precise delineation of responsibilities, both internally and in relation to other branches of government. In this regard, the continental judiciary clearly satisfies the requirements of a rigid ordering of authority. To begin with, consider that continental courts have no "inherent powers," and it is these powers that invest any structure with marginal ambiguity. Whatever authority is vested in continental courts derives from legislation. And in their desire to anticipate the future through legislation, continentals have settled jurisdictional issues relatively well. Waiting for a crisis to bring up basic problems before deciding them appears to be a style that produces too much anxiety for continentals. Furthermore, it is important to note that allocation of adjudicative authority

34. See H. Silving, Sources of Law 100, 113 (1968).

35. Ehrenzweig is probably right in claiming that the adoption of stare decisis in its continental variant would invest the continental legal system with great rigidity. See A. Ehrenzweig, PsxchoAnalytic Jurisprudence 132-33 (1971). The continental view of the legal decision explains why continental lawyers have great difficulty grasping that a legal system can grow and change by standing on precedents. They simply project their own perceptions of decisions into the common law world.

36. See J. Strayer, ON the Medieval Origins of the Modern State $50-52$ (1970). 
on the Continent invariably implies both the power and the duty to act, so that continental courts lack the option to refuse consideration of a case. ${ }^{37}$

Descending to details, a few examples of precise delineation of authority must be offered. A provision allocating the same matter either to a single judge or a panel, or authorizing both the trial and the appellate judge to render or alter the same decision, would be viewed in the continental systems as a serious ambiguity to be quickly remedied. Similarly, it would be unacceptable for a judge to be able to change his decision after he has announced it, even if such power extended only for a limited time period; once the decision is announced the court loses all power over it, and only the hierarchical superior can alter it. Relatively little difficulty is ever encountered in determining the proper adjudicator and relationships of superand sub-ordination. ${ }^{38}$

A second characteristic of rigorous hierarchies is the pronounced differentiation among judges at various levels, and in this the continental judiciary corresponds quite closely to the model. Let me begin with the courts of original jurisdiction. ${ }^{39}$ A single judge will be authorized to decide only minor offenses. ${ }^{40}$ More serious cases are allocated to a panel. If, however, serious felonies or sensitive matters such as political issues are involved, the criminal case will usually fall within the province of a higher trial court. More significantly for my purposes, many sensitive decisions that in other systems are made at the level of original adjudication are either taken away from the trial courts altogether and vested in appellate courts or removed from the judiciary entirely. For example, the idea that a trial judge could be entitled to determine whether a high government official is properly exercising his testimonial privilege, or what is and what is not in the interests of national security, appears almost preposterous from the continental perspective. ${ }^{41}$ From such a perspective, if these

37. The forum non conveniens doctrine is largely unknown, as are mechanisms such as certiorari.

38. A further problem pertaining to certitude about adjudicative powers concerns judicial disqualification, which makes clear the contrasts between an autonomous and a bureaucratic decisionmaker. From a comparative law perspective, judicial disqualification in common law countries would have to be related to voir dire. See notes 96,117 infra.

39. I am talking of ordinary courts of record. Punishable conduct of noncriminal nature (i.e., "administrative offenses") is considered by officials other than judges.

40. The practice in Holland is contrary.

41. The West German Criminal Procedure Code accords the right to the head of state to refuse to give testimony in criminal cases if he believes this to be in the national interest. German Code of Criminal Procedure $\$ 54(3)$, at 44 (Am. Series of Foreign Penal Codes, No. 10, 1965). No court is entitled to probe whether he justifiably invokes the national interest. But, if the head of state chooses to testify, even the manner in which his testimony is taken is regulated. $I d$. $\$ 49$, at 41 . 
problems are to be entrusted to the judiciary at all, it would seem natural to vest authority to resolve them in a judicial echelon corresponding to the rank of the government official whose acts are in question. Any other solution would be regarded as a serious disruption of elementary symmetry in the allocation of authority. Consider also the power to review the constitutionality of legislation. It is probably still fair to say that continentals regard the ordinary judiciary to be an inappropriate authority to strike down statutes as unconstitutional. If judicial review is allowed, it is entrusted to a special high tribunal which deviates in many ways from "normal" courts. It would be truly alien to this system to decentralize judicial review by authorizing ordinary trial judges to declare legislation unconstitutional. ${ }^{42}$ Such an arrangement would introduce a serious hierarchical disharmony. ${ }^{43}$

Let us move up the hierarchy to appellate courts. Here, one quite frequently encounters significant hierarchical differentiation. Judges normally decide cases in small panels; some important matters, however, come within the province of super-panels whose legal views are binding on ordinary panels. In this manner internal or infra-court echelons of authority are created. As shown before, this is especially important at the supreme court level. ${ }^{44}$ Nor is it unusual that a rudimentary hierarchy may appear even in a single panel, in the sense that rules evolve which accord certain powers to the president and other powers to the full panel. This should come as no surprise. To a considerable extent, this ranking accompanies the elaborate and extensive reviewability of decisions; later, when recruitment and promotion techniques are considered, it will become even more significant.

42. On judicial review in Europe see M. Cappellettr, Judicial Review in the ConTEMPORARY WORLD 54.66 (1971). The abhorrence of a diffuse power to review the constitutionality of statutes can be explained otherwise than by the low esteem in which trial judges are held. But surely it would appear incongruous to continentals to let a low bureaucrat, often a young novice, review the legislative determination. Where this is permitted at all (as in West Germany or Yugoslavia), the trial judge can only find the statute constitutional. If he suspects its possible unconstitutionality, he must suspend the proceedings and refer the issue to the constitutional court.

43. For further examples of decisions removed from lower to higher courts because of the importance of the issue involved, consider provisions such as $\$ \$ 121,122$ of the West German Criminal Procedural Code, authorizing only higher courts to extend preliminary detention beyond a certain time limit. German Code of Criminal Procedure, supra note 41 , at $71-72$.

44. See note 27 supra. An extreme case of such differentiation, leading to the possibility of internal review, is the arrangement found in the supreme courts of the Soviet Union. See H. BERMAN, supra note 7, at 92 . Higher courts in the Soviet Union can take cases away from lower courts and decide them themselves, Code of Criminal Procedure OF THE RSFSR art. 40 (1972), although this power is apparently seldom exercised. In most continental systems, however, such powers of higher courts would be an unacceptable, sometimes even unconstitutional, deprivation of the citizen's right to have "the judge determined by statute." Not even the intermediate appellate level can be skipped. 
The last demand of a rigid ordering of authority is that courts be treated as units, distinct and separate from their judges. This precisely correlates with the hierarchical model.

Consider first the situation in which a matter falls within the province of a single judge. Even after a particular judge has been assigned to decide the matter, all motions and briefs must be directed to the court on which the judge sits, rather than to him personally. And when he has rendered his decision, he has spoken for the whole court. Thus, the same matter cannot be considered again by another member of the same bench thereby creating complexities and duplications. For example, a party denied bail cannot turn to another judge in the hope of obtaining it. Most of the time, however, criminal matters will be in the province of a panel whose behavior is rooted in the long continental tradition of collective decisionmaking. ${ }^{45}$ Not surprisingly, the panel is elevated into an abstract, faceless legal creature, a sort of corporate personality. It is thus not unusual to find continental systems in which opinions are not even signed by the individual judges who wrote them. Judicial dissents are neither orally announced nor published. While many reasons are advanced in support of this arrangement, there is only one which in my view goes beyond the surface of the continental system: ${ }^{46}$ Where a hierarchical organization created for the sake of assuring unity and certainty is not forced to be unisonous, especially at the top of the pyramid, the animating presuppositions of the whole structure are strained, and the criteria for decisionmaking become either completely elusive or affected with a germ of dissolution. ${ }^{47}$

45. The old French maxim juge unique-juge inique expresses the fear of entrusting the power to decide cases to a single person. I cannot consider here the extent to which this attitude is connected with the reluctance of continental monarchs to delegate sub. stantial authority to a single individual.

46. Reasons frequently mentioned are the desire to prevent outside interference with the adjudicative process and to enhance public confidence in the administration of justice. See, e.g., R. ScHLEsincer, supra note 10, at 157 . Even in a rare continental jurisdiction such as Norway which permits the announcement of dissenting opinions, dissents are quite rare, especially on points of law. See Andenaes, Reasons for differences of opinion on questions of law, in 15 Scandinavian Studies IN LAw 29 (197i).

47. The fact that constitutional courts in a few continental systems have recently begun to permit publication of dissents perhaps only strengthens the point made in the text. Constitutional courts are viewed as "political" tribunals, deviating from the "pure" model of courts. Although judges may be permitted to disagree on political questions, even at inordinate length if they so desire, in legal matters there must be "true law," necessarily unisonous rather than contrapuntal. For further insight into the "institutionalization" of agencies participating in the administration of justice and the underlying desire for unity and order, consider the "monocratic" organization (Führerprinzip) of prosecutorial offices. See, e.g., M. Vellani, Il Publico Ministero nel Prociesso (1970). Broader studies would probably also have to encompass differences between the common law and civil law concepts of corporate personality. 


\section{Preference for Determinative Rules}

It is common knowledge that officials must have considerable leeway in solving many of the problems involved in the administration of criminal justice. The exercise of official discretion ${ }^{48}$ seems at once more natural and desirable in this area than in many others. It is therefore all the more remarkable that continental systems insist even here on guiding officials by precise standards, and are quite reluctant to be satisfied with vague principles and policies as guidelines for conduct. To outside observers, continental attitudes sometimes seem to reveal symptoms of a mind which has lost all touch with reality, whose aspirations have become utterly quixotic. This is, then, a question of great importance for comparative studies, and it must be traced from the police stage, where it is least pronounced, to the prosecutorial and judicial levels.

a. The Police. A general feature of continental police forces is a high degree of regimentation and pervasive regulation. This feature escapes those observers who identify regulation with external normative constraint on police forces. However, both a strict hierarchy and a professional tradition favor a great deal of internal regulation; uniformity, consistency, and internal review by superiors are routine. In fact, the saturation of police forces with internal regulation bears a strong resemblance to that of the military. As a result, the police tend to assess situations with reference to existing internal regulations. Substantial discretion tends to gravitate to higher echelons of the police hierarchy; lower levels are guided by rules and subjected to extensive internal control.

As far as external constraints are concerned, relatively few normative standards can be located in most continental codes of criminal procedure. It is startling, considering the importance of police work in all modern systems, to reflect on the meager regulation of police inquiries as compared to that of prosecutorial or judicial investigations. ${ }^{49}$ Significantly, however, except in the area of minor crime, most continental countries refuse to concede to the police the authority to decide whether or not to invoke the criminal process. This is seldom explicit, but rather follows inferentially from a variety of arrangements. For example, in West Germany and Yugoslavia, official agencies, including the police, are legally bound to report all criminal

48. See note 6 supra on the use of the term discretion.

49. In some continental countries procedural theorists insist that the police stage precedes the institution of criminal proceedings, and that therefore the law of criminal procedure does not apply to the police. But these internally influential opinions must bc rejected on a broader comparative plane. 
activity to the prosecutor's office. Thus, at least as a matter of legal norm, the police must forward to the prosecutor all information on criminal conduct. ${ }^{50}$ While it would be naive to assume that all such information actually reaches the prosecutor, this legal obligation creates a moderating influence on temptations to exploit police discretion. Also contributing to this result is the particular role of the victim in continental proceedings, to which I shall turn in discussing the continental public prosecutor.

b. Public Prosecutors. Although there are numerous kinds of decisions on which prosecutors can have more or less freedom from normative standards, most people would agree that the central issue is whether the public prosecutor should have broad discretion in instituting criminal proceedings. On this question, at least in cases of serious crime, ${ }^{51}$ the practice of continental countries can be classified into two groups.

The first and larger group espouses the principle that, given the initial probability that a serious crime has been committed, public prosecutors must press charges as part of their official duty; this is the principle of mandatory prosecution (Legalitätsprinzip; principe de legalité des poursuites).52 It can hardly be maintained that as a result of the operation of this principle the public prosecutor has no leeway in deciding not to prosecute. ${ }^{53} \mathrm{But}$ his freedom in doing so is seriously

50. See Jescheck, supra note 17, at 510; Yugoslav Code of Criminal Procedure articles $137,139$.

51. As regards minor crime, continental prosecutors have a great deal of leeway. Sometimes this is openly acknowledged as a matter of legal doctrine. For West Germany, see, e.g., J. Langbein, Controlling Prosecutorial Discretion in Germany, 41 U. CHI. L. REv. 439 (1974). In a number of countries, however, for various ideological reasons, the prosecutor is expected as a matter of legal folklore to prosecutc fully even minor crime. But it is not hard to find in all countries numerous alternative devices providing the prosecutor with the necessary flexibility. One such prosecutorial "cushion" lies in the substantive provisions spelling out the definitional elements of criminal offenses. Conduct which satisfies the definition but presents only insignificant "social danger" is denied the character of a crime. See, e.g., art. 7(2) Criminal Code of RSFSR; art. 4(2) Yugoslav Criminal Code. Such provisions give prosecutors asylum from the rigidities of legal folklore. Rather than justifying their failure to prosecute minor crime by reasons of inconvenience or some other factor, they simply say that there is no crime at all. Thus, rationalizations change, but the actual effect is the same as under systems where the principle of mandatory prosecution does not apply for minor crime. For other alternatives see, e.g., art 7 Criminal Procedural Code of RSFSR. This is not to say, however, that in refusing to prosecute minor crime, continental prosecutors are not bound by internal prosecutorial rules.

52. This principle was adopted by the French Revolution as a postulate of equality and disseminated throughout Europe. There are exceptions to this principle for some political offenses, juvenile delinquency and-of course-minor offenses. For such exceptions in West Germany, see Jescheck, supra note 10, at 513. France has since repudiated the idea of mandatory prosecution.

53. For a realistic recent appraisal of the situation in West Germany, see G. KAISER, Strategien und Prozesse Strafrechtlicher Sozial.kontrolle 78-86 (1972). An unavoidable flexibility stems clearly from the appraisal of the initial probability that a crime has been committed. 
limited, and there are effective pressures on him to abide by this normative mandate. Within the purview of this essay it is enough to point to arrangements whereby the victim of crime, in one way or another, can check the prosecutor's refusal to press charges. ${ }^{54}$ In addition, there are less visible but extremely important internal constraints on the exercise of prosecutorial freedom; within the hierarchy of the prosecutor's office there are regulations guiding the decision of whether to invoke the criminal process. For instance, oral or written directions instruct the prosecutor as to the significance of first-offender status in regard to specific offenses, or the point at which property damage becomes minimal. Accordingly, prosecutors often press charges contre coeur, or against their personal wishes, led to their decisions by normative directives.

The second and smaller group of continental countries authorize the public prosecutor to decline prosecution, even with respect to serious crime, if such a decision appears to be in the public interest; this is the principle of expediency (Opportunitätsprinzip; principe de l'opportunité des poursuites). ${ }^{55}$ It is tempting to associate this principle with broad prosecutorial freedom from normative constraints, but to do so would be a serious mistake. The victim, who partakes in prosecutorial activity under this system as well, may institute prosecution if the public prosecutor fails to do so, and this alternative restrains official discretion. More importantly, prosecutorial freedom is once again confined by extensive internal regulation, which reflects the emphasis placed on consistency and uniformity of decisions. Where rules can be formulated, instructions and circulars will flow profusely down hierarchically defined channels; where contours of experience prove elusive, frequent conferences will be convened, in efforts toward the formulation of ever more articulate guides. ${ }^{56}$ Once established, these standards will be enforced throughout the hierarchical pyramid.

c. The Judiciary. It stands to reason that the vaguer the decisional standard adopted, the more difficult it becomes to reconsider the resultant decision. A judicial organization cannot be seriously committed at once to both regular review and broad discretionary powers without succumbing to a sort of institutional schizophrenia. Obviously,

54. One example is the method by which the victim can secure from the court a mandamus ordering the prosecutor to press charges (Klageerzwingungsterfahren). Another is the Austrian invention of a "subsidiary charge" preferred by the victim if the public prosecutor fails to prosecute. Of course, in victimless crime, external pressures on prosecutors to institute proceedings are weak.

55. This is, for instance, the present system in France, Belgium, Holland and a limited number of other European countries.

56. Only a few internal guidelines become visible-those formulated at the very top of the hierarchy and published. 
then, because it values appellate review so highly, the continental judiciary necessarily favors standards as lucidly defined as possible. In the absence of the jury as the autonomous decisionmaker par excellence, this is not overly difficult.

Most comparatists would probably agree that continental criminal legislation, both substantive and procedural, purports to cover all problems that can be anticipated, including the very exceptional situation. ${ }^{67}$ Permissive as opposed to mandatory language is quite rare. This, of course, furnishes to decisionmakers only the broad framework of normative standards. But broad legislative standards are made more concrete by the judicial hierarchy, both within and without actual litigation, and the normative output of higher courts is quite rigid. Consistency, mutual compatibility of rules, perhaps even an order of analysis within the resulting normative universe are maintained by "legal science."is

But norm-saturation is not the only relevant consideration; attitudes towards norms are also important. It would be a serious mistake to think that this attitude is independent of the authority structure. Comparatively speaking, the attitude of the continental judiciary toward normative standards can easily be classified as rigid and unbending. Norms are not regarded, even in procedure and practice outside the trial context, as instructions from which there are legitimate departures. The great deference of the continental judiciary toward legislation is one of the loci communes of comparative law, and this is only partially mirrored in the uneasiness of the ordinary judiciary concerning the constitutional review of statutes. Equally important is the meticulous observance of norms emanating from higher courts. In sum, rules regulating the behavior of the continental judiciary are not only relatively precise and prolific, they are also comparatively inflexible.

We can now begin to understand some intellectual habits of continental judges and the idiom of their debate. Both have struck outsiders as abstract, and yet capable of easily producing accurate answers.

57. On the substantive side, duress and necessity are good examples. With respect to procedural problems, see, e.g., note 41 supra. The law of evidence, governed by the "principle of frec evaluation," seems to be an exception. The absence of norms in this area does not significantly free the continental judge. Factual findings must be justified in his opinion and are subject to review. Low-visibility rules have developed in all judicial hicrarchies regarding evidentiary questions. On the reasons for the legislative abdication in evidentiary matters see Damaška, supra note 1 , at 514-15.

58. On continental legal science generally, see, e.g., J. Merryman, supra note 5, at 65-72. On the science of criminal law specifically, see Ryu \& Silving, Toward a Rational System of Criminal Law, 32 REv. JUR. U.P.R. 119 (1963). 
Where law is not interwoven with the tradition of deciding cases in all their intricacy, the knowledge of law is not necessarily a knowledge of details.

\section{Importance of Official Documents and Reports}

Implicit in the ubiquitous hierarchical control of the continental machinery of criminal justice is the importance of documentation. Traces of all official activity must be preserved for possible review by superiors. Thus files must be maintained on all official matters, and these files can be closed only in accordance with precise rules. All official activity must be recorded and even minor decisions and their justifications reduced to written form. The part played by paperwork, ministerial matters, and bureaucratic minutiae in the total effort of officialdom is quite considerable.

Documents and reports drafted by officials are highly formalized. Specific matter must be included in specific parts of documents. ${ }^{59}$ Exposition must be succinct and summaries made whenever possible. ${ }^{.00}$ Even the style of writing is standardized: It frequently becomes arid, impersonal, and cliché-ridden. ${ }^{01}$ Personal expression, even in a jeweled and coruscated style, is anathema. Usually, tendencies toward individualism are rooted out during one's novitiate in the bureaucracy. As a consequence, anything but an impersonal stylus curiae would constitute a display of bad taste and lack of professionalism.

The great importance of this wealth of documentation, most of which ends up in the file of the criminal case, cannot in candor be denied. This is lost to many continental theoretical writers, overimpressed by the reduced role of dossiers in criminal cases after the abolition of inquisitorial procedure. ${ }^{62}$ Concentrating on the trial stage, they stress that evidence which has not been brought out during trial

59. Sometimes proper inclusion is of great practical significance. For instance, as a rule, only matter included in the "ordering part" of continental criminal judgments becomes res judicata. During their novitiate fledgling officials must learn exactly what
must be included into the ordering part, and how it should read.

60 . Thus, for instance, testimony will very seldom be taken verbatim. Instead, short summaries of what witnesses said filter information through the transforming screen of legal relevance.

61. There are of course differences of degree among various continental countries inter sese. For instance, the style of the French Cour de Cassation would be at the formal pole, while the Swedish judgments fall close to the other extreme. But even the latter are far removed from the personal, often lengthy expression of common law judges. See generally J. WeTter, THe STYles of APpellate Judicial Opinions (1960).

62. In inquisitorial proceedings the decision was based solely on the written file. Quod non est in actis non est in mundo was the maxim of the day. Even in the French revolu. tionary assembly, enchanted as it was by English viva vox proceedings, reliance on anything but written documents was vigorously opposed as an attempt to "ecrire sur de la neige." Compare A. Esmein, supra note 11, at 434 . 
may no longer be used in arriving at the decision, due to the "principle of immediacy."'Bs But when all the usual arguments have been made, the fact remains that the dossier still constitutes the backbone of criminal proceedings. Note particularly that in almost all continental countries the presiding judge studies the file in advance of the trial, and that many important documents from the file can be read aloud in court as evidence. ${ }^{64}$ Finally, the extent to which a cloistral calm, unperturbed by viva vox, permeates the appellate process must be obvious to anyone who comes from a less bureaucratic system.

\section{Behavior Expectations}

On this last point of comparison between existing continental systems and the hierarchical model I can be very brief, for much of what I would have to say has already been mentioned. ${ }^{65}$ It will be recalled that the 18th century vision of decisionmaking as an automatic process of norm application has been recognized as a rationalist illusion and rejected as a practical proposition; it has remained, however, as a regulating ideal. ${ }^{60}$ Often the obscured constituent of complex processes, this ideal can best be perceived in existing role expectations, and some of these can, I believe, be factored out as representative of the continental machinery of criminal law enforcement.

Officials are not supposed to be autonomous decisionmakers, but are instead expected to adopt the behavioral idiom of civil servants. Guidance for official activity must be sought in the corpus of official norms, so that all problems appear primarily as technical administrative questions. Professional craftsmanship is a highly valued asset. ${ }^{07}$ When no standards for decisionmaking exist, and independent

63. See Damaška, supra note 1, at 517; H. LöHR, DER GRUNDSATZ DER UNMITTELbarkeit IM DEUTSCHEN STRAFPROZESSRECHT (1972) (monograph on West German aspects, with comparative comments).

61. For details, see Damaška, supra note 1 , at 519 .

65. See, e.g., pp. 506.07 supra (the rigid disciplinc enforced in writing decisions); p. 506 supra (the handling of documents and dossiers); p. 500 supra (the hierarchical ordering inside a given court); p. 490 supra (comprehensive review on appeal).

66. See p. 495 supra.

67. The tendency of continental systems to treat legal and political issues as technical problems has been noted in, e.g., $\mathrm{R}$. DAHRENorf, supra note 3, at 230; K. MANNrim, IDEOlogs AND UTOPIA I05 (1949); H. SpIRo, Government by Constitution 285 (1959). The attitude that legal activity is more a craft and a technique than a political pursuit can be traced to Greek antiquity, where the craft of lawmaking was considered antecedent to political activity, just as in continental ideology lawmaking is subsequent to basic political choices. H. Arendr, The Human Condition 173 (1959). Professionalism creates pressures for specialization even at the top of the hierarchy which explains why continental supreme court judges sit in specialized panels. A general problem-solving capacity does not suffice; to allow litigants to supply technical knowledge ad hoc would be, in the continental view; a surrender of an essential aspect of judicial activity. Extreme specialization also exists in continental law schools. A continental instructor teaching in as many fields as American law professors would probably be viewed by his colleagues as a dilettante. 
action becomes unavoidable, it must be exercised sparingly, with extreme moderation and preferably at the apex of the hierarchy. ${ }^{68}$ Moreover, this norm-creation by officials is supposed to proceed as an activity guided by internal rules of the craft, that is, by autonomous principles of the normative order, and it should never be influenced by political, ethical or similar extrinsic values. The great hostility toward decisionmaking on the basis of such considerations clearly permeates the ideology of all continental countries. Indeed, apocalyptic consequences are feared for the legal system as a whole if officials in the law enforcement machinery are permitted to engage in such unrestrained decisionmaking. The most dreaded consequence is not the obliteration of the separation of powers, within which policy questions are for the legislator to decide; after all, this principle is often viewed, especially in the East, as a formal organizational device of dividing functions. The primary fear goes deeper. It is generally believed that decisionmaking divorced from the restraint of the normative order brings the curse of uncertainty. Uniformity is undermined and replaced by the wilderness of single instances. And in the resulting chaos law itself, gradually but inexorably, dissolves into politics. ${ }^{69}$

Notwithstanding important local variations, mechanisms to assure conformity of behavior to these expectations can easily be identified in all continental countries. It is probably not too far fetched to regard even university training as a factor in shaping attitudes desirable in the machinery of law enforcement. The view is there imparted that the normative order contains, at least in embryonic form, the solution to all problems. Broad panoramic vistas of neatly delineated legal fields are offered to students, and the unmistakable emphasis is probably still on acquiring knowledge of what has authoritatively been said, rather than on the manner of thinking which generated those authoritative pronouncements..$^{70} \mathrm{But}$, no matter what the influence of university training, the period of practical novitiate for

68. At the top, independent action is not limited to minor matters even in the criminal law area. See H. Silving, supra note 34 , at 88.

69. This apocalyptic scenario is reflected almost verbatim in a 1954 decision rendered by the West German Constitutional Court, itself a "marginal court," admittedly more politicized than ordinary courts. See 3 ENTSCHEIDUNGEN DEs BuNDESVERFAssungsGrRICIITS 225 (1954). And it is this vision which has prompted a famous French comparatist, looking at American law, to declare in desperation that, with the weakening of the force of precedents, law itself has been weakened. A. TuNC \& S. Tunc, LE DRoIT DEs ÉTAT-UNIS D'AMÉRIQUe 163, 183 (1955). Judicial legislation is opposed also by the legal ideology of Marxian socialist countries. See note 29 supra.

70. Elsewhere I have tried to define the continental mos jura docendi the mode of teaching law). See Damaska, $A$ Continental Lawyer in an American Law School: Trial and Tribulations of Adjustment, 116 U. PA. L. REv. 1363 (1968). 
official positions is in almost all systems an initiation to bureaucratic techniques and modes of thinking. ${ }^{71}$ The successful socialization into this world is then tested by entrance examinations, which are even organized for aspirants to judicial positions. Finally, the desire of career people to advance makes the system of promotions a very potent weapon in enforcing conformity with expected official conduct. ${ }^{72}$

\section{The Coordinate Model}

\section{A. General Characteristics}

\section{The Object of Coordination}

Animating the coordinate model is the aim of reaching the decision most appropriate to the circumstances of each case. Certainty of decisionmaking is recognized as an important value, but is less weighty than in the hierarchical model; what appears to be the best solution in a particular case will not be readily sacrificed to certainty and uniformity of decisionmaking. Consequently, the distinction between saying that a particular decision is just and that it is in accordance with the law cannot as easily be made as in the hierarchical model. The cast of mind underlying these value preferences attaches great importance to the rich variety of experience and is skeptical of attempts to impress general structures on the complexities of life.

\section{The Coordinate Organization}

The desire for particularized justice requires that officials be close to the concrete situations of life involved in the processing of cases, and, of course, that they be free from outside constraints in considering equities. If achieving particularized justice were indeed the sole concern in the coordinate model, the ideal system would be a single layer of authority; but the need for a degree of uniformity is recognized, and the necessary unification of policies cannot always be achieved through the voluntary cooperation of autonomous officials. Accordingly, more complex structures of authority must be composed.

71. See, e.g., R. Schlesinger, supra note 10, at 95 (West Germany and France); M. C.uppelletti, J. Merriman \& J. Perillo, supra note 23, at 86, 104 (Italy).

72. See M. Beradt, Der peUTSChe Richter 7-21, 42-80 (1930) (masterful attempt to sketch the psychology of the German judge). A common law reader would find this portrayal quite inapplicable to the judiciary of his own system. 
When hierarchical structures of authority must be established, the basic value orientations of the coordinate model mandate that the ordering of authority be as mild as possible. Three attributes of such a mild hierarchy are important for my purposes. Because of the aversion to defining the relation of each official to the center of authority, positions of sub- and super-ordination are not clearly delineated. The resulting ambiguities and occasional overlappings are willingly accepted as a necessary price for the fundamental commitment to autonomous official powers. In keeping with the importance of the first layer of authority, the inequality among officials on various rungs of the hierarchical pyramid is not very pronounced; essentially, they are all homologues with similar authority inherent in their positions. And lastly, when officials must be organized into a unit, they do not thereby totally surrender their independence. Office and incumbent are not fully separated. The unit does not become an institution divorced from the real people comprising it.

Because officials must tailor their decisions to the special, sometimes unique circumstances of individual situations, the desire to predetermine the outcome of cases by precise and unbending rules is repugnant to the coordinate model. This is not to say, of course, that there are no preexisting standards for decisionmaking at all. Standards do exist, but they tend to be less precise and more flexible than in the hierarchical model. The general theme of "official discretion"73 runs like an obbligato through all aspects of official activity. Moreover, it is consistent with the model to entrust crucial decisions to independent bodies of laymen. In such a setting there is no need for officials to make a record of all their activities, or to write down and justify even minor rulings. And where written decisions and reports appear warranted, standardization and regimentation of style appear as unnecessary and irksome formalisms, perhaps not fully compatible with the dignity of official positions. Generally speaking, bureaucracy in the coordinate model is rudimentary.

The structure of authority emerging from the foregoing brief sketch generates quite different behavior expectations than those encountered in the hierarchical model. Obviously, the ideal official is not a technical expert applying normative directives, irrespective of what appears to him to be the best solution in the light of the circumstances of individual cases. Decisionmaking is not a technical or administrative problem with policy issues settled in advance, but rather involves

73. See note 6 supra. 
the more exalted and responsible activity of finding the best solution to a social problem in light of the political and ethical values of the decisionmaker.

This different role expectation in the coordinate model is reflected in the requirements for official positions. The importance of both professional training and a period of apprenticeship is minimized or totally eliminated. A candidate for office is preferably an established person who has made his mark in society, a problem-solver attuned to community values. Since socialization to a bureaucratic world is not necessary, even the highest positions may be entered laterally, that is, by outsiders without previous experience in the machinery of criminal justice. ${ }^{74}$

\section{B. The Coordinate Model and Anglo-American Reality}

As was the case with continental countries, important variations that exist among common law jurisdictions must be acknowledged at the very outset. Some countries, the United Kingdom being one, have of late inaugurated changes bringing them much closer to continental systems. Nevertheless, a general pattern can be discerned on many crucial points in all Anglo-American countries, and it is to this general pattern that my presentation is devoted.

\section{Centrifugal Decisionmaking}

a. Police and Public Prosecutors. It may be said with only a modicum of exaggeration that both in England and in America a police system, in the continental sense, hardly exists. Although professional forces originated in the 19 th century, they remain to the present day

74. The relationship of the briefly outlined coordinate model to Weberian typologies is uncertain; Weber himself found that the common law system eluded his taxonomy. Yet one might reasonably ask why the hierarchical and coordinate models are not polarized with respect to the impersonal (or detached) style of exercising authority as Weber similarly polarized the bureaucratic and various "traditional" types of authority. I think this opposition is impossible, given the unusual constellations of personal involvement in both models. Consider whether or not officials perform their duties as part of a permanent occupation; the extent of lay involvement; the visibility of individual destinies (frequently submerged in the neutral shelter of normative propositions); how many, and how crucial, the decisions made at the level of original jurisdiction; all these factors seem to turn one way. Yet other features confound this easy polarity: For example, the more elevated the position of the autonomous decisionmaker the more likely the social distance to be great between officials and ordinary persons, and this increases with an increase in autonomy. And note the role of the aims of the criminal process itself. If one of the tasks of the process is not only to consider people's activities but also their personalities (e.g., in an attempt to change them), officials tend to get more personally involved in the processing of cases. Finally, I must point out the passive character of the ideal coordinate judge and add that passivity can easily lead to aloofness. The variations smudge any clear contrast between the two models on this point. 
deeply imbedded in local institutions and are in most respects wholly decentralized. The jurisdiction of such police organizations as the FBI in the United States and Scotland Yard in the United Kingdom remains severely restricted..$^{75}$

The situation is similar with respect to professional public prosecution. England still gets along without any real counterpart to public prosecutors' offices, with the "system of popular prosecution" (actio popularis) remaining the theoretical foundation. ${ }^{70}$ In most American states, public prosecutors are locally elected officials with surprisingly great and virtually uncontrolled authority. Even where state attorneys general do possess some powers to coordinate local law enforcement, these powers are seldom exercised. While the federal prosecutorial arm is centralized, hierarchical subordination is negligible by continental standards. ${ }^{77}$

b. The Jury. The common law jury is a classic example of an autonomous decisionmaking body in the administration of justice. No doubt, it is also a centrifugal force. Consider only the issue of jury nullification. In the face of uncontroverted evidence, and in the teeth of clear judicial instructions, the jury may bring in a verdict of acquittal and thereby refuse to apply substantive law, whether centrally imposed by the legislature or developed through judicial lawmaking. The frequent justification for this power is that jurors must bring to bear local conceptions of justice upon decisionmaking and adjust the crude substantive criminal law to the circumstances of individual cases. ${ }^{78}$ But even if the jury verdict is one of conviction and may therefore be set aside, decisions as to fact, law and substantive justice are so deeply entangled in the general verdict that continental review can hardly be imagined. ${ }^{79}$

75. Police decentralization sometimes continues even beyond the municipal level, as in New York City. See Danzig, Toward the Creation of a Complementary Decentralized System of Criminal Justice, 26 STAN. L. REV. 1, 20 (1973).

76. See R. Jackson, THE MAchinery of Justice in ENGland 120 (4th ed. 1964).

77. U.S. PRESIDENT'S COMM'N ON LAW ENFORCEMENT AND ADMINISTRATION OF JUSTICE,

TASK ForCE RePoRT: The COURTS 73-77 (1967).

78. Note, however, that the jury may most freely exercise this power of adjustment in favor of the defendant. They cannot blatantly alter the substantive criminal law in order to convict a defendant who would otherwise go free. The adjustment rationale is linked to the challengeability of verdicts, and ultimately to the structure of power in the criminal process. See P. Devlin, TRIAL BY JURY 89 (1956) (England). For a recent judicial discussion of jury nullification in America, see United States v. Dougherty, 473 F. $2 \mathrm{~d}$ 1113, 1130-37 (D.C. Cir. 1973). See generally Kadish \& Kadish, On Justified Rule Departures by Officials, 59 CALIF. L. REv. 905, 925 (1971); Note, Toward Principles of Jury Equity, 83 YALE L.J. 1023 (1974). The centrifugal potential of jury nullification is almost the same, even if it is viewed solely as a factual power rather than as a "legal right."

79. In addition, the inscrutable character of the general verdict has contributed to the relatively unrefined nature of substantive criminal law. See S. Milsom, Historicar, Foundations of THE COMMON LAW 361 (1969). While the continental variant of the jury 
It is true that in all modern common law systems, and especially in the United States, jurors decide only a miniscule fraction of the total volume of criminal cases. Nevertheless trial by jury remains an ever-present practical possibility; more importantly for my purposes, the jury is a paradigmatic concept around which ideologies and legal sensibilities crystalize.

c. The Judiciary. It is well known that England was the first Western country to develop uniform judicial institutions and to achieve unity of law. This fact alone might seem to indicate that the judiciary in common law countries is very far removed from the decentralizing ideals of the coordinate model. Curiously enough, however, many striking features of judicial decentralization survive in the modern adjudication of criminal cases. But before I turn to these features, let me engage in a temporary petitio principii and try to explain this curious phenomenon.

A good starting point is to recall the unique features of, and limitations on, the centralization of justice in medieval England. Discussions of centralization and the unification of law customarily concentrate on the operation of central royal courts. In an abridgment of a much more complex phenomenon, one may say that English kings created a single, rather undifferentiated system of courts of original jurisdiction for the whole country, rather than a hierarchical structure. Because of the relatively small scale of operation and the very small number of judges, it was possible to maintain in informal ways the necessary degree of unity and consistency of adjudication. Judges formed close-knit groups and regularly engaged in informal consultation. $^{80}$ No internal hierarchical differentiation or appellate system was needed to achieve uniform decisionmaking by individual judges. ${ }^{81}$

In discussing the administration of criminal justice, however, it is wrong to focus on central royal courts at all. They were, after all, created primarily for the legal needs of the dominant social classes, and crime usually involved hoi polloi. The disposition of the great bulk of criminal cases was entrusted to the local gentry-the justices of the peace-who acted in partnership with local juries. No need

trial adopted a form of special verdict, see note 21 supra, hostility toward such verdicts prevails in common law countries to the present day. For a recent example from American federal courts, see United States v. Spock, 416 F. 2d 165, 180.81 (Ist Cir. 1969); cf. Heald v. Mullaney, 16 CriM. L. Rer. 1035 (lst Cir., Nov. 13, 1974).

80. On various techniques used to develop unity of law within royal courts, see $\mathbf{M}$. Hale, The History of the Common law of England 251-52 (1820).

81. Consider how different this historical experience is from the continental development, where the monarchs developed a many-layered bureaucracy and an appellate system which reached local levels of administration, but were never strong enough to displace. local customs and unify the law. 
was felt for institutionalized forms of central supervision over the work of local potentates. Various extraordinary legal devices, designed to bring matters before the central royal judges, were seldom used in criminal matters, and the administration of criminal justice remained to the 19th century "a notable essay in decentralization." 82

Whether in royal courts or local ones, criminal cases involved onelevel adjudication. Quite naturally, then, the entire criminal process became identified with the trial, and the conclusion of this stage signalled the end of the criminal proceeding. ${ }^{\$ 3}$ This conception of the criminal process, springing as it does from decentralization, has not disappeared even now from Anglo-American law. Although obscured by the twisting route in which its implications have been circumvented or subordinated to modern needs, the importance of single-level adjudication can be observed without great difficulty; it is especially apparent in the interplay between the original adjudication and appellate review, which came relatively late to the common law world. Let me present a few illustrations from American law in support of this proposition. ${ }^{84}$

Because the notion has not been entirely discarded that the decision of the trial court terminates the criminal proceeding, appellate review seems to conflict with the guarantee against double jeopardy: ${ }^{85}$ Review appears as a "new jeopardy" rather than the continuation of the original one.

Artificial constructs (such as the defendant's waiver) are invoked to avoid this conflict. Similarly, the reconsideration of acquittals appears as a violation of the prohibition against successive prosecutions for the same act. And, to the bewilderment of continental observers, the defendant must obtain a stay of the trial court's decision pending appeal.86

The lasting vitality of the notion of trial adjudication as final also ac-

82. T. Plucknett, A Concise History of the Common Law 169 (5th ed. 1956).

83. At common law, the pleas of autrefois acquit and autrefois convict prevented reconsideration of criminal cases on appeal and retrial for the same offense. This practice was reflected in the debate on the original draft of the Fifth Amendment. See 1 ANNALS of Conc. 730, 781-82 (1789-1791).

84. It should be noted that England has in this century moved closer to the continental system of liberal review. However, this trend should not be exaggerated; for example, the English appeal from questions of facts and from the sentence is not a matter of right, but typically depends on leave of court. See R. Arguile, Criminal ProCEDURE 171 (1969). See note 95 infra. For some useful remarks in a generally neglected area of the history of appellate remedies in common law countries, see L. B. ORFIELD, Criminal Appeals in America 14, 56 (1939).

85. See Benton v. Maryland, 395 U.S. 784 (1969), overruling Palko v. Connecticut, 302 U.S. 319 (1937); North Carolina v. Pearce, 395 U.S. 711 (1969).

86. From the continental point of view all Anglo-American appellate remedies would be classified as "extraordinary" rather than "ordinary"; cf. note 15 supra. Since stays are nowadays granted as a matter of course where decisions are reviewable, any distinction 
counts for the relatively limited scope of appeal. Leaving aside the fact that acquittals cannot be appealed on any ground, consider the comparatively severe limitations on the grounds for the defendant's appeal. Both the factual findings and the sentence imposed can hardly be challenged. Even when error can be appealed, direct reconsideration of the adjudication, as in the continental system, is not involved. Following the pattern quite understandable in the setting of the jury trial with its inscrutable general verdict, what is actually reviewed is the propriety of the material submitted to the decisionmaker for decision, rather than his "correct" use of the material. ${ }^{87}$ In light of the foregoing it is not at all surprising that the right to appeal is not nearly so important in Anglo-American as it is in continental systems, and that it is generally not accorded constitutional stature. 88

The continued importance of original jurisdiction, with the accompanying lesser importance of the appellate process, invests the Anglo-American judicial system with strong centrifugal tendencies. Judges retain important autonomous powers typical of a decentralized judiciary: Like the jury, they can nullify substantive criminal law; ${ }^{89}$ the unreviewability of acquittals gives them significant leeway in deciding evidentiary issues; and the scope of their sentencing power is astonishing by continental standards. ${ }^{90}$ As a result, centralization of policies cannot be achieved nearly so easily as it is in the hierarchical systems.

\section{Mild Ordering of Authority ${ }^{01}$}

Beginning again with medieval England, we must recall that courts, much as amoebae in the primordial biological soup, were for a con-

has been made virtually irrelevant for the purpose of obtaining a stay. But the concept of original adjudication as a basis for res judicata and execution of judgment causes other problems which have not been clearly resolved in the case law (e.g., the use of convictions pending appeal for the purpose of impeaching the defendant at another trial).

87. 'Typical questions explored on appeal are whether the evidence was properly admitted, or whether the jury received proper instructions. The question of whether, given the proper informational sources, the "correct" result was reached is not considered. By contrast, in continental systems, this question too is subject to review.

88. See Griffin v. Illinois, 351 U.S. 12. 18 (1956); Ross v. Moffitt, 417 U.S. 600 (1974); North Carolina v. Pearce, 395 U.S. 711 (1969).

89. See, e.g., Model Penal Code $\$ 2.12$ (Proposed Official Draft, 1962) (purporting to codify prevailing practice).

90. Continental lawyers would object to "provisional sentencing" (e.g., 18 U.S.C. \$ 4208 (b) (1970)) as placing unacceptable pressures on defendants to conform to whatever the judge demands. Consider also the example given by $D$. Newan, Conviction: The Determination of Guilt or InNocence without Trial 178 (1966). See Mfueller \& LePoole, supra note 12 , at 418 (on the continental system).

91. Because police forces and prosecutorial offices in Anglo-American countries are seldom centralized, I may, perhaps, be allowed to neglect any minor hierarchies existing in this area and concentrate solely on the ordering of the judiciary. 
siderable time quite undifferentiated. Some became stationed at Westminster; others travelled around the country, possessed by l'humeur vagabonde. Consistency of decision was maintained in informal ways; little need was perceived for clear and rigid internal organizational arrangements, and it was thought unnecessary to establish a judicial hierarchy linking the center with local adjudicators. Consequently a mildly hierarchical but quite complex court structure with somewhat ambiguous organizational arrangements persisted until the court reforms of the last century. ${ }^{92}$

I $\varepsilon$ is striking that, notwithstanding the vast differences in the scale of operation, many of the mildly hierarchical features of the British court system exist in America. The most important of these features must be examined in some detail.

Characteristically, a penumbra of uncertainty exists in the circumscription of judicial authority in the United States. It springs mainly from the fact that American courts, including those in the federal system, are not "creatures of legislation" in the continental sense. Judges retain certain "inherent powers," independent of the legislative delegation of authority. Nor is there much anticipatory legislation concerning the division of authority, if only because even the lower courts possess some "rulemaking" power. ${ }^{93}$ Indeed, legislation on what could be termed judicial competence is so meager that, with its blank areas, it appears to continental lawyers to resemble early maps of Africa. Overlappings frequently occur in the jurisdiction of courts at different levels. For instance, the trial judge, for a time, following the announcement of his decision, shares with higher courts the power to alter the judgment; moreover, a stay of execution may be sought from either the court of original jurisdiction or from the appellate court. As a final illistration of ambiguous relationships, anathema to the hierarchical model, consider the power of federal district court judges in habeas corpus proceedings to review state supreme court decisions, both in deciding whether to use the existing record and in invalidating convictions of state courts rather than merely disturbing the custody of prisoners based on such convictions. ${ }^{94}$

92. The latest reform, which went into force in 1972, brought the English court system closer to the simple continental model. Nevertheless, carryovers from the past (such as judges differentiated in title) remain within certain courts. See Grzybowski, Court Reform in England, 21 AM. J. CoMP. L. 747 (1973).

93. Such rulemaking power, even if specifically delegated solely to the supreme courts, is almost beyond the comprehension of most continental lawyers. Courts with which they are familiar are mainly limited to issuing insignificant rules of order. Greater flexibility and, consequently, uncertainty also stem from the freedom of some American courts to refuse to consider a case falling within their jurisdiction. On the continent such a practice would be a clear instance of "denegatio justiciae."

94. See Brown v. Allen, 344 U.S. 443 (1953). 
In accord with another distinguishing feature of the mild ordering of authority, trial judges are allocated many powers which a rigid hierarchy would either vest judges at a higher level, or deny to the judiciary altogether. An obvious example is the power to strike down legislation as unconstitutional. ${ }^{95}$ But even more remarkable is the cause célébre of a federal trial judge determining-albeit in the first instance only-the proper limits of the President's executive privilege. ${ }^{90}$ Within the hierarchical model issues of such magnitude would never be entrusted to the lowest judicial echelon.

In yet another respect the Anglo-American judiciary is accurately represented by the coordinate model: Individual judges, even when on a panel, preserve their independence and identity. Thus, for instance, the common law system has never accepted the idea, so typical of hierarchical structures, that the court as a unit has spoken when a judge belonging to its bench has rendered his decision. ${ }^{97}$ And, when a panel issues a decision, it need not speak with one voice; indeed, a requirement that individual opinions be forgone would run counter to basic ideas of the autonomy and dignity of judicial office. Consequently judges are entitled to deliver individual opinions, even if this implies, as in the Japanese fable of Rashomon, that the same story is recounted from various standpoints and there is no discernible opinion of the panel as such.

\section{Preference for Flexible Rules}

a. Police and Prosecutors. One of the most important tasks of the police and public prosecutors is, of course, to stand as Cerberus at the entrance gate of the criminal justice system. Their decisions concerning which cases to admit and which to exclude are notoriously difficult to regulate, especially through relatively rigid standards imposed from outside their respective organizations. Although a measure of discretion, exercised in concrete circumstances, seems at once necessary and unavoidable, continental systems have attempted to deny both the police and public prosecutors freedom from normative con-

95. This power does not exist in the United Kingdom.

96. See United States v. Nixon, 94 S. Ct. 3090 (1974); Reynolds v. United States, 345 U.S. 1 (1953). Compare the less dramatic problem decided by the House of Lords in Conway v. Rimmer, [1968] A.C. 910. A further example of powers that would be unacceptable in the hierarchical model is the discretion of American judges to decide whether they must disqualify themselves because of bias. A finding of such bias would in a hierarchical system be made either by the chief judge or-more likely-by the higher court. For contrasts with the continental systems, see notes 41,43 supra.

97. For example, the denial of bail or of a stay of execution by one judge does not prevent his colleague on the court from granting it. See Holtzman v. Schlesinger, stay denied, 414 U.S. 1304 (1973). 
straints. Similar efforts are not apparent in Anglo-American systems. Consider the decision of police officers whether to invoke the criminal process: In the absence of a centralized police organization, there is comparatively little concern with overall uniformity and thus only minimal internal regulation exists. Moreover, existing standards cannot be as effectively enforced here through internal supervision as in a rigid hierarchical police structure.

What about external constraints imposed by the courts or the legislature? Without broad participatory mechanisms such as the victim's right to invoke the initial stage of the criminal process, there is little effective control over police decisions not to investigate or arrest. Thus the freedom of police officials from normative constraints in deciding what matters to pursue, quite considerable in all systems, seems somewhat more pronounced in Anglo-American countries. ${ }^{98}$

While some will surely dispute this conclusion on the independence of the police, for admittedly only nuances are involved in the difference, few would be prepared to deny that the Anglo-American public prosecutor has considerably more freedom from regulation than his continental counterpart. A typical American district attorney comes quite close to the very ideal of an autonomous decisionmaker. His decisions not to prosecute are practically unchallengeable, a circumstance all the more significant because the victim of the crime does not have the right to institute formal criminal proceedings. Once the prosecutor has decided to pursue a matter, there are comparatively few legal constraints on his determination of how many charges to squeeze out of the criminal transaction, ${ }^{99}$ and there is very little law on the question of whether charges pertaining to the same event must be pressed together or seriatim. ${ }^{100}$ Moreover, prosecutorial freedom in plea-bargaining is virtually total. Finally, since there is no centralized prosecutorial organization, the great freedom of individual

98. This, I believe, is true even of those police forces which have abandoned the traditional "watchman" style and adopted the "legalistic" style of work. See generally J. Wilson, Varieties of Police Behaviour 140,172 (1970). In the United Kingdom the police prosecute most offenses and their exercise of "discretion" is generally accepted. Se' G. Williams, Discretion in Prosecuting 3 CRIM. L. REv. (ENG.) 222 (1956).

My statement in the text should not be taken to imply that judicial control over police on the continent is generally more effective; rather, internal constraints, and the more pronounced role of the victim, are in part responsible for the comparatively less discretion available to continental police. With his large automous powers in the area of excluding evidence, the Anglo-American judge actually possesses stronger weapons to affect police work than does his continental colleague.

99. Continental criminal law seems to be much more elaborate and specific. See $\mathrm{H}$. Silving, Constituent Element of Crime 62, 175-97 (1967).

100. In most continental systems re-prosecution following a nolle prosequi faces some double jeopardy obstacles. Unlike the common law system, where double jeopardy ideas revolve around the trial, continental countries attach jeopardy to criminal proceedings so that problems appear earlier and continue until the appellate process comes to an end. 
prosecutors from normative constraints is not limited by internal regulations aimed at assuring the uniformity and consistency of decisions.

Such unfettered prosecutorial discretion is not very striking from the comparative perspective, for substantial official leeway from precisely articulated standards can be encountered in many criminal justice systems. It is when we turn to Anglo-American adjudicators, i.e., the judge and jury, that much more considerable contrasts arise.

b. The Adjudicators. The Anglo-American adjudicator of criminal cases may be characterized by his freedom from settled and precise substantive law, and his flexible attitude toward rules, be they substantive or procedural.

In discussing the substantive criminal law, experts commonly assert that problems belonging to what continental lawyers would call the "general part" (such as principles of criminal liability, the unit of criminal conduct, and the definition and sufficiency of charges) are in a fluid and comparatively unrefined state. ${ }^{101}$ That this should be so will not surprise anyone familiar with the spirit of what $I$ have called the coordinate model. Problems of criminal law are not authoritively structured in advance, for it is feared that such attempts to capture reality in the mesh of rules may hamper the attainment of particularized justice. It is thought that the task of refining the law is done best in the context of individual cases, by people both familiar with the concrete details and attuned to community values. Unusual cases that contribute so much to the complexities of the law are infrequent, and prosecutors often decline to prosecute when such cases occur. ${ }^{102}$

101. One cannot deny, of course, that there is of late in almost all common law countries a great deal of very sophisticated writing on substantive criminal law problems. But this writing differs from the continental one in at least two characteristic respects. Firstly, its major effort is directed towards the criminalization decision and purposes of punishment, areas which, from the continental perspective, lie in a "meta-juridical" zone, and are more appropriately the concern of politicians, philosophers and sociologists. One finds relatively little analysis of the formal structure of substantive criminal law, particularly inspired by a desire to establish a sort of neutral algorithm for helping lawyers to arrive at a given result in dealing with substantive criminal law problems. Secondly, where analogues exist to the continental analysis of problems belonging to the "general part" of criminal law, there is almost no agreement on the conceptual matrix from which one can proceed to cumulative scholarship. Both in theoretical writing and in decisions, one tends to go back to fundamentals. Using Kuhn's language, the discipline seems to be in a "pre-paradigmatic" stage. See T. KunN, The STRUCruRe of Scienrific Revolumons 11 (2d ed. 1970). Nor is this strange, if only in view of the fact that in common law jurisdictions criminal law has only of late become the business of lawyers. See S. MiLsom, supra note 79, at 353 . If this is true of substantive criminal law, it certainly does not apply to criminal procedural law. The latter is replete with arabesques of technical refinement and is often exceedingly complex. See p. 527 infra. But, as we shall see, even in the field of procedure and evidence, many important issues are left to the discretion of the decisionmaker, and what I shall say about judicial attitudes toward substantive legal rules applies equo rationae to the law of procedure.

102. Under the coordinate model no rational prosecutor would bring the defendant to trial in the exceptional circumstances that constitute a borderline problem in the law. A different result may occur under the principle of mandatory prosecution. 
Those cases that are brought within the criminal justice system are usually left to the adjudicator's general verdict, from which concrete standards simply cannot be distilled. ${ }^{103}$ In sum, what to continental eyes appears as a sorry state of affairs, resembling the charmingly confusing Chagallian universe of freely floating objects, represents in the setting of the coordinate model a perfectly natural and desirable arrangement.

Much more important than the relatively large areas of substantive law that are not in fact governed by rules is the Anglo-American adjudicator's disposition toward those rules that do exist. In contrast to his continental counterpart, he finds little that is sacrosanct about them and regards certain departures as perfectly legitimate. Let me present a few examples. Of course, a judge in the Anglo-American system can question the constitutionality of rules, and such rules are therefore not inviolate; and it is obvious that where a judge can decide these constitutional challenges, basic policy issues will often surface. But even in those cases where constitutional objections to rules are not raised, precedential or legislative standards will be discarded or modified whenever they indicate a result contrary to the adjudicator's strong beliefs as to the best disposition of the case. Where departures from established rules lead to the acquittal of the defendant, the adjudicator's decision usually cannot be challenged. And even where his decisions are reviewable, his attitude toward rules will be far from deferential, and departures from them may be regarded as justifiable.

Generally, then, one can observe that rules in the Anglo-American system are not much more than guidelines for average cases, guidelines susceptible of improvement and reconsideration in light of current experience and the particular circumstances of each case. The premise of this attitude resides in the desire to achieve particularized justice.

But it is important for comparative purposes to note that, in this concept of adjudication, decisionmaking becomes inevitably enmeshed in concrete situations and even minor details. Legal questions cannot be debated grosso modo, and efforts can hardly be made to develop law as a system of interrelated legal standards. Adapting a felicitous phrase from another context "a tradition of behavior is not

103. Frequently questions of determining facts and establishing normative standards will be combined and treated as an issuc for the jury to decide, as with negligence problems. The extent to which this arrangement discourages the development of substantive law is a more general phenomenon. See David, Les caracteres originaux de la pensé juridique anglaise et américaine, in 15 ARchives dE PhILOsophIE DU DroIT 6 (1970). 
susceptible of the distinction between essence and accident; to know the gist is to know nothing." 104

\section{The Informal Style}

The autonomous manner of exercising authority that is so characteristic of the Anglo-American machinery of criminal justice must inevitably decrease the importance of official documentation and bureaucratic techniques. ${ }^{105}$ There is in the Anglo-American criminal process no real counterpart of the continental dossier; in fact, even writing judicial opinions is regarded by many judges as an opportunity for the expression of self, so that, by continental standards, many judicial opinions appear more like products of littérateurs than official documents. And this applies even to periods in which the common law followed what Llewellyn has termed the formal style. ${ }^{\mathbf{1 0 6}}$

In this scheme, it would not make sense to suggest that decisionmaking should place great reliance on official documentation. Indeed, much of the law of evidence is designed to prevent such an occurrence. Summaries of testimony or of visits to the scene of crime, for example, assume the character of lifeless bureaucratic residues of reality, always defective, often spurious, and therefore such evidence is normally inadmissible at trial. The best substitute for the viva vox as a basis for decisionmaking at the trial is the full transcript, for this comes closest to reproducing the full complexity of reality that is so crucial to adjudication in the coordinate model.

\section{Behavior Expectations}

As a result of differences in the respective authority structures, the objective role expectations of Anglo-American officials present a sharp contrast to those engendered in continental systems. Because the goal of the common law process is justice within the individual case, re-

104. M. OAkeshott, Rationalism in Politics and Other Essays 128-29 (1962). Bentham's remark that common law, conceived as a system of rules, is "a thing merely imaginary" is thus not as preposterous as it might initially appear. J. BENTHAM, A Comment on the Commentaries 125 (C. Everett ed. 1928). Sec A. Simpson, supra note 31, at 88-99, for a modern and quite persuasive argument that common law cannot be understood as a system of rules.

105. In this area, some professionalized Anglo-American police forces come closer to the bureaucratic continental style than do other official bodies. Of late, efforts are observable to make American judges state the basic reasons for imposing a particular sentence. See ABA Model Sentencing ACt $\$ 10$, in ABA Standards Relating to Sentencing Alternatives and Procedures, Tentative Draft 333 (1967).

106. The "chassé-croise" between more or less formal styles can be detected even within the "common law tradition", but such shifts are negligible when constrasted to the continental idiom. Compare decisions of the French Cour de Cassation with examples of the formal style offered by $\mathrm{K}$. Llewellyn, JuRISPRUdence 306 (1962). 
course by its officials to substantive values, such as social policy or ethical considerations, is part of the very essence of their activity. Taking refuge in the neutrality of the legal craft and its universe of norms, while closing one's eyes to what appears desirable in the light of concrete circumstances, is not fully compatible with the dignity of the office. The ideal official in the Anglo-American system is not so much a professional expert as a wise problem-solver, attuned to the values of the community.

Mechanisms to sustain such behavior expectations can, at least in America, be readily located. The first influence is exerted by the system of legal education. ${ }^{107}$

For instance, panoramic vistas of fields of law, conceived as an orderly normative whole, are not offered at all in law school, for they would appear as hollow immensities of dubious value and of an uncertain relationship to reality. The open-endedness of issues is stressed from the very first day of school, so that freshmen will be socialized to a world in which there are few mooring places and little certainty. Most of the time in class is spent debating policy issues, making mental efforts to resolve them under professional guidance. After law school, there is neither a practical apprenticeship nor an entrance examination for official positions, although such events are crucial to the shaping of the sensibilities of continental officials. High office can be entered without any prior bureaucratic experience; candidates for official positions, even at the lowest level, are preferably prominent persons who have behind them careers as politicians or lawyers. Finally, because incumbents of official positions are established people who do not differ widely in importance and prestige on the various echelons of the hierarchy, the desire for advancement does not appear to be as pronounced.

The result of such behavior expectations and training is that the personnel manning the Anglo-American machinery of justice are relatively unwilling to tolerate the low profile and multiple constraints of bureaucracy. Officials are generally forceful and willing to make independent decisions; thus, even at the lowest echelons, few officials

107. Until recently some officials in the Anglo-American system of justice were not even required to be lawyers. In modern times university legal education has been required increasingly, for at least the judicial office, but there are still well known exceptions, such as justices of the peace and some county prosecutors. Moreover, within AngloAmerican law schools, specialization is not nearly as narrow as in European universities, and the path to teaching positions is not as arduous as in most continental countries. See H. Jacob, Justice in America: Courts, Lawyers and the Judicial Process (1965); David, supra note 103, at 5. 
display a typically bureaucratic mentality, while at the top it is not surprising to find "charismatic" personalities. ${ }^{108}$

\section{The Structure of Authority and the Conventional Typology of Criminal Proceedings}

Two models of authority structure have now been presented. If they successfully capture some essential aspects of the contrast between continental and Anglo-American systems of criminal justice, the next inquiry then becomes their relationship to the conventional dichotomy between adversarial and nonadversarial types of procedure, where this latter set of terms is used to focus on comparisons of process at the trial stage. ${ }^{100}$ Are authority structures and processing styles independent, or is one set of models, either of authority structure or processing style, ultimately subordinate to the other? This is an intriguing but very difficult question. Fortunately, for the purposes of my article, I need not explore all analytically possible or historically known combinations of authority structure and processing style in the administration of criminal justice. Nor need I consider the labyrinthine problem of which combination is analytically the best match. Instead, my attention centers on the actual combinations that present themselves in the limited field of my comparative inquiry. Accordingly, in the present part of the article I propose to consider only those issues that arise when the coordinate model is paired with adversary procedure, as is the case in Anglo-American countries, and the hierarchical model is matched with nonadversarial proceedings, which occurs in continental jurisdictions.

\section{A. The Judge at Trial}

When the positions of the continental and Anglo-American judge are viewed from the different perspectives afforded by authority and process models, a curious puzzle emerges. The Anglo-American judge

108. In using this term, defined in the Weberian sense, I refer particularly to the judiciary. Notice in this connection how little specialization is encountered at the apex of the judicial hierarchy in Anglo-American countries. Charismatic leaders are not technical specialists; the necessary technical knowledge for their pronouncement is supplied to them ad hoc by the litigants, masters, or amici curiae.

109. I have clsewhere criticized the use of these models to explain the contrasting legal systems. See Damaška, supra note 1, at 561-65. Nonetheless, the descriptive force of the traditional dichotomy is not limited to the trial stage. It also illuminates the prosecutorial role before trial. In the adversary system, the prosecutor is driven into a relatively pronounced opposition to the defendant in anticipation of the trial. The police in AngloAmerican countries similarly act in anticipation of an adversary trial with high evidentiary barriers to conviction. One factor that explains differences in police behavior between continental and common law systems is the greater divergence in the latter between what the police actually know and what can be introduced as evidence at trial. 
has great autonomous powers, but his ideal stance is that of a relatively passive umpire of the adversary process. His continental counterpart is less autonomous, but assumes an active role. It seems strange that the strong is expected to be passive, while the weak is supposed to be active; indeed, many would be inclined to view this combination as an analytical mismatch.

Attempts to explain this bizarre merger must await an analysis of those factors that affect the actual choices of structure and style. ${ }^{110}$ In this section, I shall inquire into the features of this curious combination in an effort to illuminate the relationship between models of authority structure and models of trial design.

Let me begin by first taking the Anglo-American side of the comparison. The passive posture of the judge is historically novel ${ }^{111}$ and far from being a general description of the judicial office. Instead, it applies only to a limited number of procedural contexts and to a restricted class of issues. Judicial passivity is the rule only during the guilt-determining phase of the trial, and there serves as the norm only with regard to the framing of the subject matter of the proceedings, the collection of evidence, and the presentation of proof.112 Even in this limited segment of their activity, Anglo-American judges are not rigidly restricted: If a judge believes that abiding by his ideal role will adversely affect the proceedings or poorly serve the public interest, he will usually abandon his detached stance and vigorously intervene in the conduct of the trial.113 And even though much of

110. See p. 529 infra.

111. See note 156 infra.

112. By passivity in framing the subject matter of proceedings I refer to the arrangement whereby the parties themselves determine which claims and defenses to press or to waive. In recent times some Anglo-American jurisdictions have permitted the judge to raise certain defensive issues. See note 137 infra. Where this has happened, a departure from the adversary model must be acknowledged.

By judicial passivity in collecting evidence I mean the absence of requests by the judge that the parties furnish an evidentiary source, e.g., that a witness be called. Most theoretical writers would agree that if the judge goes beyond merely suggesting to the parties that particular evidence be produced, he is deviating from the adversary style. But see F. JAmes, Civil Procedure 5-7 (1965). That judges should be passive in the presentation of proof is correctly viewed as less central to the ideal of adversary proceedings; asking questions of witnesses is compatible with the adversary style. United States v. Liddy, Crim. No. 1827-72 (D.C. Cir., Nov. 8, 1974); United States v. McCord, Crim. No. 73-2252 (D.C. Cir., Dec. 12, 1974) (see opinion of court at 17-22). But if the intensity of such judicial activism exceeds a certain point, the judge clearly deviates from his proper rolc. Finally, it is frequently forgotten that the stance of passivity applies a fortiori to the jury.

113. Some of these deviations from the passive role can be explained by a desire to correct the malfunctioning of the adversary system. Adversary proceedings require an approximate equality between the parties in order to function properly, and if the balance of advantage is seriously affected, the judge may intervene. If his redress of the balance helps the defendant and results in acquittal, his conduct is unreviewable. If he supports the prosecution and conviction follows, the propriety of such assistance is of course subject to review. See e.g., United States v. Guglielmini, 384 F.2d 602, 605 (2d Cir. 1967). As we shall see, however, not all judicial activism can be explained along these lines. 
this intervention is technically limited to suggestions to the parties, these "suggestions" will typically be heeded, for both parties will be reluctant to risk unfavorable and often unchallengeable judicial decisions on other matters. Judicial passivity, however, is recognized as an ideal posture only in limited situations. In many phases of the criminal process, such as pretrial hearings, in camera examinations, and the sentencing stage, passivity and aloofness come to an end. Indeed, at these junctures in the proceedings Anglo-American judges occasionally assume outright inquisitorial postures that are without counterparts in modern continental systems. ${ }^{114}$

And no one would be more surprised at such powers than the continental judge at trial. It is true that he is the source of most procedural activity: $\mathrm{He}$ is responsible for determining the subject matter of the proceedings, ${ }^{115}$ and for securing all evidence needed for the ascertainment of the truth. During the proceedings, he not only presides over the taking of proof, but also originates the bulk of questions. ${ }^{116}$ The continental trial judge, however, must expect superior review of all his rulings as a matter of course, and is rigidly restricted by a network of rules and customary practices. He has much less independence from normative constraints than his common law counterpart, and also much less power over the parties and other participants at the trial. ${ }^{117}$

It follows from the foregoing that the conventional characterizations of judicial activism in the two systems are of limited explanatory value. An analysis based on differences in the type of authority can provide a greater insight into a broader range of judicial activity

114. The prosecution for the break-in at the Watergate headquarters of the Democratic National Committee provides a controversial example. Judge Sirica decided that it was in the public interest to proceed to an inquiry beyond the prosecutorial charge. He refused to accept the guilty pleas (see N.Y. Times, Jan. 12, 1973, at 1, col. 1; at 24, col. 6) and imposed unusually harsh "provisional" sentences (up to 40 years). See United States v. Liddy, Crim. No. 73-1564 (D.C. Cir. Dec. 12, 1974) (see MacKinnon, J., dissenting, at 16-17). This second measure produced results: one defendant decided to talk, and the Watergate scandal was brought to the door of the White House.

Ever since the 19th century reforms, continental judges, whether trial or investigative, have had neither the authority to exceed prosecutorial charges nor such wcapons as "provisional sentencing" to put pressure on defendants to cooperate. More generally, observe the broad equity powers of the Anglo-American judge in civil cases. It is the denial to the continental judge of comparable, flexible powers (especially of supervision) which explains more than anything else the absence of the device of the trust in the continental legal system.

115. He is, of course, confined to the prosecutor's charge, but within its limits the judge must raise all relevant issues; and thus there are, for example, no "affirmative" defenses in continental law.

116. For limited exceptions, see Damaška, supra note 1, at 525 n.38.

117. There is hardly a counterpart in continental systems to the contempt powers of the common law judge. Parties may also seek judicial disqualification more easily than in the common law system. See, e.g., $\$ \$ 22-31$, German Code of Criminal Procedure; N.Y. Times, Apr. 14, 1974, at 11, col. I (request for removal of Judge Sirica). 
than can the traditional dichotomy between active and passive roles. Indeed, this is the case even in those areas to which the traditional view is applicable since it must admit numerous deviations from the type of judicial behavior one would expect on the basis of the traditional dichotomy.

\section{B. The Complexity of Procedural Issues}

Still another seeming anomaly appears when the two models of authority structure are related to the adversarial and nonadversarial styles of procedure. It will be recalled that officials in the coordinate system are free from precise and stringent legal standards, and do not regard themselves as legal technicians. But the adversary trial in which they operate has a complex structure; much of the law of evidence and procedure is intricate, replete with technicalities. In continental systems the situation is just the opposite: Nonadversary proceedings are comparatively simple, there is relatively little law of evidence, ${ }^{118}$ yet the process unfolds before officials who perceive themselves as legal technicians and willingly assume normative constraints.

In attempting to explain this puzzle I must separately consider three issues. First, I shall determine which authority structure is likely to generate more complicated procedural law. Second, I shall inquire whether procedural complexity reduces the decisionmaker's freedom from normative constraints, and whether procedural simplicity leads to the opposite result. Finally, I shall make a few comments on the relationship between the degree of the technical complexity of law and the need for the advance training of officials, for it is this relationship that establishes the different self-perceptions of officials in the two systems.

Which model of authority structure is more likely to create legal complexities? The hierarchical model is possessed by the desire for certainty and uniform decisionmaking. But certainty and uniformity cannot be achieved without ordering, and the latter in turn implies a degree of abstraction. One cannot establish order without rearranging and eliminating whatever does not fit the order-determining principles. ${ }^{110}$ Those who think otherwise may be likened to a gardener trying to create a formalized French garden, while refusing to trim and eliminate individual plants.

118. But see note 57 supra.

119. Examples of this are the preference for brief summaries of relevant facts rather than full transcripts and the neglect of factual description in judicial opinions. 
The coordinate model, with its strong attachment to individualized justice, is less willing to neglect the particular in the interest of ordering. ${ }^{120}$ Denuding individual cases of those circumstances irrelevant to ordering principles appears as artificial as French topiary art seems to a devotee of the loose and free English gardening style. ${ }^{121} \mathrm{But}$ this too comes at a cost. The coordinate model must accept a relatively high degree of complexity in its law as the price for a relatively low degree of order in its normative structure. ${ }^{122}$

There is another circumstance bearing on the issue of procedural complexity. Where, as in the coordinate model, the adjudicators are autonomous and much of their decisionmaking is largely unchallengeable, procedural problems arise and assume great importance which are quite secondary or even irrelevant within other systems. At trials to an autonomous adjudicator one cannot afford to be lax in regard to potential sources of error in adjudication, since they often cannot be corrected through review. Quite naturally, then, assuring the adjudicator the proper informational input before he decides the case assumes central importance. This is the stage at which parties believe they can have control over the process. Intertwined with the question of guilt, structural questions as to the admissibility of evidence and the proper scope of counsel's behavior have to be litigated before

120. It was Burke, I believe, who saw the characteristic feature of liberty in the complexity of institutions and a danger of tyranny in their simplification; $c f$. G. DE RUgGiero, The History of Eurorean LiberalisM 99 (1959).

121. The horticultural metaphor is not so farfetched. The classical French garden strikes one as highly rational, just as rationalist attitudes underlie the hierarchical model. By comparison, the English garden seems less orderly, which accords with the Weberian idea that nonbureaucratic organizations are of low rationality. Note also that "the heated controversy during the eighteenth century between defenders of the formalized French garden and the partisans of the looser English style must surely be considered one aspect of the fight for liberalism against the rigid autocracies of the past." R. ARnherm, Order and Complexily in Landscape Design, in Toward A Psychology of ART 125 (1972). The reader should remember this aesthetic parallel when, in the next part, I turn to the problem of ideologies supporting procedural models.

122. As far as the desire for logical symmetry and clear ordering of the law is concerned, England and continental European countries began to drift apart long before the age of codification on the Continent. Of course, I cannot offer concrete proof of the greater simplicity of continental criminal law in the precodification period; I can only invite the reader to compare a mid-17th century German book on criminal law with an early 18th century English work on the same subject. Compare B. Carpzov, Practica NOVA RERUM CRIMINALIUM IMPERIALIS SAXONICA, supra note 11, with W. Hawkins, PleAs OF THE Crown (1824). Bear in mind that Carpzov was not a mere theorist, comfortably removed from decisionmaking, but a busy judge in Leipzig. On the other hand, Hawkins was not solely a product of empirical education, but a Cambridge graduate as well. The historical explanation of the greater ordering and intellectual symmetry of continental law is very complicated. Emphasis on different patterns of legal education as an explanatory factor goes back at least to Weber. See M. WEBER, RECHTSSOzIoLocie 197-201 (1960). For a recent exposition of this view in English, see Coing, The Roman Law as Ius Commune on the Continent, 89 LAw Q. REv. 505 (1973). In addition, the development of judicial administration was radically different in England than on the Continent. For the curious English development, see S. Missom, supra note 79, at 32, 37, 72, 79. 
the trial is over. In this scheme it is not unusual to find a symbiosis of autonomous decisionmakers and a caste of highly skilled technical experts whose main purpose is to make sure that the adjudicator is exposed to the proper informational material. ${ }^{123}$

What is the situation in the hierarchical model? Because all decisions are in principle reviewable, a heavy emphasis on prophylactic rules would be misplaced and undesirable. It would only burden the consideration of the merits with "collateral" issues. ${ }^{124}$ Moreover, without such a burden, the role of continental lawyers is correspondingly different, and their primary orientation is toward the substantive resolution of the case.

It is thus quite natural for the coordinate model to generate more complicated procedural law than does the hierarchical model. This, however, should not be taken to mean that the freedom of officials in the coordinate model is consequently more narrowly circumscribed. Rather, the attitude of such officials toward procedural and evidentiary norms is decisive. In the coordinate model, rules can legitimately be departed from and the review of such departures is comparatively limited; accordingly, procedural and evidentiary norms are not so compelling as they seem to be in the hierarchical model. Furthermore, even if the prevailing disposition toward legal propositions were the same in both models, there is a point beyond which increased complexity of law, especially in loosely ordered normative systems, objectively increases rather than decreases the decisionmaker's freedom. Contradictory views can plausibly be held, and support found for almost any position. These characteristics are, of course, much more prominent in the coordinate model than in its antipode.

These characteristics establish, and in turn are reinforced by, the different self-perceptions of officials operating within the two models. It is significant, and not paradoxical, that adjudicators in the procedurally less technical hierarchical model regard themselves primarily as technical experts, while their counterparts in the procedurally com-

123. It is tempting to suggest that judges in the traditional common law administration of justice are legal experts assisting the actual decisionmaker, rather than decisionmakers themselves. The jury is the autonomous adjudicator, while the essential function of the judge is to supervise the flow of information and to supply the jury ad hoc with any necessary technical knowledge.

124. Technical consequences of this different orientation are Iegion. For instance, the idea of "mistrial," so important in the Anglo-American system, is insignificant or unknown in continental countries; the notion of "fair hearing" is much less central. Moreover, the prejudicial error concept of procedure has developed quite differently in the two systems. Generally speaking, continental systems appear much more reluctant than common law systems to disturb a substantively "correct" adjudication for procedural reasons. 
plex coordinate model view themselves more as general problem-solvers than legal technicians. If the individual contours of processed cases are decisive, as is the case in the coordinate model, advance knowledge of the criteria for decision is relatively unimportant. More helpful to the decisionmaker is the knowledge that can best be obtained ad hoc, in the context of litigation. The important residual of the official's own technical expertise is the normatively flexible area of practice and evidence, a rather unlikely subject for advance systematic study. More relevant to the operational demands of a coordinate system than a technical knowledge of norms is a general problem-solving capacity, social imagination, and similar nontechnical qualities.

The hierarchical model represents quite a different world. Its normative universe seems surveyable and its ordering principles, manageable information. As the importance of the particular circumstances of cases decreases, the gaining of advance knowledge of normative criteria for decision becomes a more realistic and fruitful effort. In sum, a more hospitable environment is provided for beliefs, be they illusory or not, that what is involved in making decisions is essentially a technical problem of applying predetermined legal standards.

Once again, however, my discussion of one issue has raised another, and this time broader, question. How did these curious mergers of processing style and authority structure come to pass? Is it possible that their actual choice in continental and Anglo-American countries can be related to a common determinant? It is to this question that I shall now turn.

IV. The Criminal Process and Attitudes toward Political Authority

\section{A. Procedural Models and Political Ideology}

It would betray a great deal of innocence to assume that the genesis of procedural systems reduced essentially to a more or less consistent derivation from the tenets of prevailing political ideology. The latter seldom, if ever, inexorably lead to concrete procedural choices. Furthermore, many problems of criminal procedure are matters of little controversy between ideologies, and even those ideological considerations that are relevant may be deemed less important than countervailing factors.

Consider the role of continuity of tradition. It was certainly of great importance in the gradual evolution of the common law procedure, exposed, as it was, to a variety of historical cross-currents. 
But even instances of ideologically motivated innovations in continental procedural history do not offer examples of procedural standards and practices written on a tabula rasa, but rather on a palimpsest from which the past was never completely erased.

Nevertheless, even if ideological tenets cannot causally explain specific combinations, it is worthwhile to look for possible connections between ideology and particular choices of processing style and organizing authority. In discovering affinities between ideology and criminal procedure we are actually canvassing ideological arguments advanced in support of existing procedural arrangements and in opposition to their change.

\section{Parental and Arm's Length Criminal Justice ${ }^{\mathbf{1 2 5}}$}

Theoretical writers have attempted to articulate ideological orientations that provide an explanation for basic choices in structuring procedural authority and devising procedural arrangements. ${ }^{126}$ In American scholarship, these efforts have led to two polar procedural ideologies. One, purporting to capture the fierce agon of Anglo-American procedure, is predicated upon the belief that an irreconcilable conflict between the individual and the state exists in the administration of criminal law. Because state officials cannot be trusted and consummate deviltry on their part cannot be ruled out, the best procedural design is one in which the individual and the state engage as adversaries in a highly formalized battle. The goal of criminal justice must be narrow, limited to the meting out of punishment for specific conduct; if it went beyond that, an unacceptable invasion of the individual sphere would occur.

Opposed to this ideology is the view that there is a basic congruence of interests, and perhaps even mutual love, between the individual and the state. Officials harbor parental emotions toward the defendant: $\mathrm{He}$ is viewed by them as an "erring member of the family" who has to be reconciled with and reintegrated into the community. Accordingly, state officials need not be mistrusted, they need not be limited to a passive role in the proceedings, and the ample powers they exercise need not be confiscated because of occasional abuse. Finally, the objectives of the system may be broad, encompassing even educational purposes.

125. The description in the text derives from K. Llewellys, supra note 106, at 444; Griffiths, Ideology in Criminal Procedure, 79 YALE L.J. 359 (1970).

126. For an illustration of continental efforts in this direction, sec G. Foschivr, 1 Sistema del Diritio Processuale Penale 226-32 (2d ed. 1965). 
This polarization of procedural ideologies, no matter how illuminating in other contexts, is unsuitable for the purpose of contrasting modern Anglo-American and continental criminal procedure. Although it cannot be denied that the parental ideology fits some systems known to history, these procedural systems can be found either in tribal cultures or in those modern societies that attempt to restrain antisocial conduct independently of state authority. While in the first case no state has yet developed, ${ }^{127}$ it is claimed in the second that the state is moribund, and new reactions to unacceptable behaviour are harbingers of the stateless future. ${ }^{128}$ But from the moment the state appears as a factor of any significance until such time as it actually withers away, the parental ideology may rightly be regarded with some circumspection, for it may provide a rationalization for the most brutal kinds of governmental oppression.

Leaving aside some recent but more controversial illustrations, consider the example of medieval inquisitorial procedure. Because medieval society was strongly collectivistic, and the role of government was as yet unlimited, two basic consequences of the parental ideology were present: pronounced togetherness, and a strongly "interventionist" approach to deviant behavior. Even so, the authority exercised by officials in medieval inquisitorial proceedings can hardly be explained as benevolent paternalism. The defendant did not look to the judge for guidance and protection, nor did the judge perceive the defendant in statu pupillari. The social distance between the typical defendant and the judges, or the heinous nature of the crime, usually prevented any real empathy among them. In serious cases the judges seldom even saw the defendant, invoking "acta inquisitionis" to cover a void of emotion. Thus, at least from our modern perspective, the relationship between the defendant and state officials cannot meaningfully be studied sub specie amoris. ${ }^{129}$

127. When the state has appeared but is still weak, the activity of its officials is generally limited to the supervision of contests between private individuals. Thus, while the state is still embryonic, criminal proceedings develop closer to a "battle" model than to a "parental" model.

128. Indeed, this is part of the ideological justification for East European "comradely courts" with jurisdiction, inter alia, over minor crimes. A system close to the parental ideology has recently been proposed for dealing with minor crime in American urban communities. See Danzig, supra note 75 , at 15,42 . However, this proposal may be justified more as an abdication of state authority than as its death throes.

129. However, there are indications in contemporary sources that such "parental" justifications were attempted. Punishments for some minor crimes were claimed to have been in the miscreant's own interest (poenae medicinales). And even in proceedings against witches and heretics, investigators were sometimes instructed to seek the defendant's confession so that he or she could be reintegrated into the community. See Bartolus de Sassoferrato in J. HANSEN, QUELLEN UND UNTERSUChUNGEN zUR Geschichte des Hexenwihns 66 (1901). T. Campanella, Civitas Solis Poetica (1643), offers an ex- 
Briefly, then, the polarization of parental and arm's length ideologies must be rejected for my purposes. Rather, to understand the ideological roots of the coordinate and hierarchical models, I shall contrast some unique features of classic English liberalism with several aspects of prevailing continental ideologies relevant to the administration of criminal justice.

\section{Classic English Liberalism as a Source for Procedural Choice}

a. Limited Government and Diffusion of Authority. Although it is hazardous to talk in general terms about the main themes of classic English liberalism, the views on political authority attributed to this tradition can be considered fairly representative of it. And it is precisely these views that appear quite singular from the standpoint of those continental ideologies which prevailed at the time when modern political institutions were being shaped. ${ }^{130}$

Within the conceptual horizons of classic liberalism, it seems as if society does best without the state at all. The state should be called in and its influence felt only in times of crises, when something goes wrong in the "self-governing" society; government is solely an arbiter in cases of conflicting interests or disputes. Under no circumstances may government legitimately impose specific beliefs upon citizens; the state is not entitled to guide and educate them in accordance with its own visions about the good life. This is paternalism-one of the strongest aversions of the classic liberal credo. ${ }^{131}$

Two main reasons are usually advanced for this liberal idea of limited government. The first and fundamental explanation reflects a general attitude of skepticism: Since no belief or idea regarding human affairs is exclusively or demonstrably true, it is unjustifiable to impose any such views on other people. The second reason for the ideal of limited government is related to this agnostic epistemological position: Since no one knows what is objectively best, each individual may be presumed capable of making and must be allowed to make his own

ample of a man who conceived a "parental model" of criminal justice while he languished in the dungeons of the Spanish Inquisition; $c f$. R. Marcic, Geschichte DER RechtsphiLOSOPHIE $281(1971)$. But it is not likely that such intentions to reclaim the criminal were seriously held. $\Lambda$ totalitarian state may, however, succeed in transforming socicty to the degree where parental ideologies become widely accepted; cf. K. LleweLLy, supra note 106 , at 447 .

130. In what follows I deal only with the division of governmental power among competing power units. It stands to reason that this arrangement in the political system can coexist with great, even monopolistic power concentration in social and economic areas.

131. Cf. J. Locke, Two Treatises on Government, Second Treatise $\$ 60$, at 173 (1960). 
choices in life, ${ }^{132}$ no matter how strange or even foolish they may seem to others.

But even the most extreme brands of classic liberalism recognize that there are areas of social life in which continuous state intervention cannot be avoided. Where this is the case, and the administration of justice is an example in point, great concentrations of power must be prevented and the diffusion of authority is regarded as a political imperative. There are two ways in which authority may be fragmented. The more obvious method is to distribute it along a horizontal axis, among powerholders at the same level. It is this first, Montesquieuan form that has virtually monopolized the attention of both continental and Anglo-American political theorists, particularly with regard to the upper echelons of governmental structures. But while it became part of the dominant ideology in the English-speaking world, the doctrine of the "separation of powers" never really took hold in Europe, insofar as it implies the creation of independent power centers which balance one another. ${ }^{133} \mathrm{~A}$ second way of fragmenting authority has received much less attention and is usually encountered in discussions of federalism. Yet this fragmentation is an important phenomenon, and I believe, quite typical of the intricate weave of the English political tradition of strong local self-government. It involves the allocation of authority along a vertical axis, in its "scalar" aspect; in this way, subordinated structures of government are vested with substantial autonomous powers and hence share a measure of supreme authority with the highest level of government. A mosaic of local power centers is thus created. But, as a result of the horizontal division of authority, the powers of local potentates are rather narrow, and abuses by one may be checked by the refusal of others to cooperate. It is this second form of diffusing authority, leading to minimal centralization, that

132. See C. Macpherson, The Political Theory of Possessive Individualism 244 (1962). 133. Conceived as a separation of legislative, judicial and administrative functions, the separation of powers may be said to be more rigorous on the Continent than in AngloAmerican countries; the judiciary is denied lawmaking powers, and the legislature is refused any judicial or quasi-judicial functions. But, if separation of powers is viewed as calling for the establishment of independent power centers which check and balance each other, the model becomes alien to continental political theories. Considered spurious by Rousseau, it is generally rejected because it both conflicts with the necessary unity of government and creates animated political standstills. The locus classicus on legal aspects of the continental variant of the separation of powers is still 2 C. DE MALBERG, ConTRIBUTION A LA THÉORIE GÉNÉRALE DE L'ÉTAT \$1, at 23-34 (1922). This famous French legal theorist thought the idea of checks and balances (freins et contre-poids) was tolerable in America solely because it was not extended, he mistakenly assumed, to the states, but was limited to the federal government. Id. at $22 \mathrm{n} .13$. On the enthusiastic American acceptance of the doctrine of separation of powers, see G. WoOD, THE Creation of THE AMERICAN Reipublic 151, 604 (1969); The Federalist Nos. 10, 47, 51 (J. Madison). In socialist countries of Eastern Europe, separation of powers is rejected on familiar Marxist grounds, as a cloak to hide the essential unity of the ruling class. 
is in perfect harmony with classic English liberalism but quite alien to any influential continental political ideology. ${ }^{134}$ Indeed, this second diffusion of authority constitutes one of the most striking features of the English political culture.

It would be incorrect to understand "liberalism" only in the context of its modern variants. The antipathy of classic English liberalism toward state intervention and strong central government may not be the attitude most congenial to the implementation of substantive liberal values. Indeed, a centralized state may further the development of liberal values, and it is by no means clear that central tyranny is necessarily worse than the tyranny of local potentates. Accordingly, the classic English liberal attitudes toward the state are not a necessary ingredient of the modern liberal credo; instead, they must be regarded as a matter of historical contingency, so that hostility toward the state is a product of ideological inertia, remaining from the days when power had not yet passed into liberal hands. Freedom, to classical liberals, was mainly freedom from the state, and there were only "a few presentiments" that the state in liberal hands could accomplish tasks for which spontaneous social organizations and private enterprise are insufficient. ${ }^{135}$

b. Procedural Implications of Classic Liberalism. It is hardly necessary to ask whether the ideology of classic English liberalism favors the coordinate over the hierarchical model of authority structures in the criminal process. The preference for the former follows easily from the general liberal distaste for concentrated power, and more particularly from its attachment to what I have called the vertical fragmentation of authority. Let me therefore turn to the relationship between the liberal ideology and the conventional adversarial and nonadversarial models of processing style.

In introducing this theme it is useful to step back from the usual focus for a moment and imagine the full concentration of procedural authority in the hands of only one official. An example of such a monopoly of power is the figure of the inquisitorial investigating judge. He decided on his own initiative what cases to process, and

134. Exceptions to this rule can only be found in some brands of socialist ideology (e.g., the Yugoslav "self-management") which, in an attempt to disperse authority and decentralize, Icd to legal reforms. Excepting the area of federalism there is little political or legal literature on the vertical fragmentation of authority. Much more can be learned from writings in the area of business organizations, particularly those discussing the problems of vertical integration of firms as opposed to "autonomous contracting" in the market. See O. Williamson, MARkets and Hierarchies: ANAlysis and ANTitrust ImpliciTIONS (forthcoming 1975).

135. See G. DE RugGrero, supra note 120, at 60, 135, 368. 
possessed full authority to determine any issue which in his opinion required examination. Using our modern concepts, one may say that the prosecutorial, defense and adjudicative functions were merged in this role. ${ }^{130}$ The 19 th century continental reforms of criminal procedure resulted in the dissolution of this concentration of power and led to the separation of prosecutorial and adjudicative functions. Following these reforms, the continental judge could proceed only on the motion of a prosecutor, and the subject of his inquiries was limited to the offense described in the prosecutor's charge. Although motivated by independent reasons, this separation of functions is consistent with continental political ideas on the separation of powers. But, unlike the Anglo-American system, continental procedural systems refused to go beyond this point.

The additional narrowing of judicial functions in the Anglo-American criminal process cannot be justified by any influential continental theory of the relationship between the state and the individual. However, it may be understood with reference to classic English liberalism. Let me show this by considering a number of examples.

The proposition that the defendant be given a monopoly over most defense issues, and be permitted to discharge them as best he can without judicial interference, finds no support in prevailing continental political ideologies, and is generally alien to continental legal culture. ${ }^{137}$ Classic English liberalism provides an easy justification for this arrangement: The defendant is presumed to know what is best for him, and since no one else can establish better knowledge, no official has the right to impose his views on the defendant. Within the adjudicative function that exists after the prosecutorial and defense functions have been severed, a further fragmentation may take

136. Where the judgment was rendered by a panel of judges, as was the case in scrious matters, a similar concentration of functions took place. Deciding essentially on the basis of the investigative dossier, the pancl was supposed to act simultancously as prosecutors, defense counsel, and judges.

137. As part of his official dutics the continental judge must raise all defense issues for which there is some support in the case. Any other arrangement is viewed as risking the conviction of an innocent person. The trend in modern Anglo-American law is away from the radical position under which the clefense has a full monopoly over defense issues. For instance, some jurisdictions authorize the trial judge to raise the issue of insanity on his own initiative. See, e.g., United States v. Robertson, Crim. No. 1631-71 (D.C. Cir., Oct. 22, 1974); Whalem v. United States, 346 F.2d 812, 819 (D.C. Cir. 1965). But it is significant that the drafters of the ALI Model Penal Code rejected this arrangement as "too great an interference with the conduct of the defense." Model Penal Codf $\$ 4.03$, Comment at 194 (Tent. Draft No. 4, 1955).

Another consequence of divesting the judge of defense functions is that the collection of exculpating evidence becomes basically a private enterprise; cf. Brady v. Maryland, 373 U.S. 83 (1963). This laissez-faire atmosphere so pervades the Anglo-American system that the advent of "public defenders" for the indigent defendant may be viewed by many as a considerable innovation. 
place if the defendant so desires. The crucial function of determining guilt can be taken away from state officials in all but minor criminal cases and vested in a group of citizens. And if the latter refuse to convict the defendant, no matter what result seems to be mandated on the basis of the ascertained facts and applicable law, their decision is in this respect sovereign. ${ }^{138}$ Thus the Anglo-American judge's role begins to resemble the ideal role of the state in the liberal vision of society: Both state and judge are transformed into arbitrators, supervising societal conflicts. In sum, then, the limited functions of the Anglo-American judge, so central in the adversary type of trial, reflect both the idea of limited government and the horizontal division of authority. ${ }^{139}$ But because authority is also vertically fragmented, the judge retains great autonomous powers, and, free from a comprehensive superior review, can depart from his theoretically narrow role whenever necessary to achieve justice.

The classic liberal ideology, however, provides support for more than the fundamental matrix of the adversary type of trial. Again consider the defendant's role. Continental lawyers often marvel at the degree to which crucial decisions in the Anglo-American system of criminal justice are withdrawn from state officials, and consequently withdrawn from legal norms and rational and objective decisional standards.

It is the operation of the defendant's choice, rather than of an inexorable procedural rule invoked by the state, which determines the mode of processing to be applied in his case. If he decides not to oppose the charge, an extremely informal "adjudication by consent" will typically follow, no matter how serious the offense involved. Where charges are contested, the decision whether to have a trial by jury or

138. I should reiterate at this point that $I$ am concerned with possible liberal justifications of existing procedural arrangements, rather than trying to prove that such arrangements actually derive from liberal tenets. The division of functions between judge and jury antedates liberalism by centuries.

139. The horizontal division of authority is also noticeable in the denial to the AngloAmerican judge of full authority to decide whether an arrangement between the prosecution and the defense accords with the public interest; under existing law, the judge shares this authority with the public prosecutor. It can be argued that under a pure adversary model the parties should be sovereign in their arrangements, the prosecutor acting as sole guardian of the public interest. A similar issue on the role of the judge also arises in connection with acceptance of the defendant's guilty plea. See United States v. Ammidown, 497 F.2d 615 (D.C. Cir. 1973). See generally North Carolina v. Alford, 400 U.S. $25(1970)$.

Some scholars claim that this narrowing derives from notions about the best allocation of functions between parties to the dispute. See F. James, Civil Procedure 4 (1965). It is unclear, however, why such notions about optimal allocation are entertained-as far as criminal matters go-only in the Anglo-American system. 
judge is again usually made by the defendant. ${ }^{140}$ On the Continent, by contrast, separate types of processing are chosen in accordance with predetermined rules: the more severe the offense, the more elaborate the proceedings. There is very little that the defendant can do to change this arrangement, and nothing at all in case of serious crime..$^{141}$

This division of roles also applied to the transplanted jury system which, once imported, soon suffered a decline. Throughout the jury's checkered history on the Continent, the legislature specified the catalogue of crimes, usually only of the most serious kind, which were triable to a jury. The defendant had no say on the matter, no waiver of jury trial was permitted, for the provision was jus cogens. Similarly, if the Anglo-American defendant refuses to be represented by counsel, the system cannot force him to do so, no matter how grave the charges, and despite the fact that optimal functioning from within the adversarial mode requires lawyers on both sides. The defendant has the moral right "to stand alone in his hour of trial."142 This notion is rejected by continental systems, although defense counsel is there not nearly so crucial as in the Anglo-American system. Continental law mandates that, if certain serious criminal charges are involved, the defendant must be represented by counsel irrespective of his insistence on acting pro se..$^{143}$

As a final illustration, consider the problem of illegally obtained

140. In legal theory, the decision concerning a jury trial does not reside exclusively in the defendant. See Singer v. United States, 380 U.S. 24,25 (1965) ("We find no constitutional impediment to conditioning a waiver [of jury trial] on the consent of the prosecuting attorney and the trial judge when, if either refuses to consent, the result is simply that the defendant is subject to an impartial trial by jury..."). In fact, however, his choice is usually honored. See Note, Government Consent to Waiver of Jury Trial under Rule 23(a) of the Federal Rules of Criminal Procedure, 65 YALE L.J. 1032 (1956) ("Ordinarily government consent to waiver may be obtained as a matter of course...").

141. Where a minor crime is involved, the defendant can influence the mode of processing to some degree. Remote counterparts to pleading guilty have a long tradition in some continental countries. See, e.g., the French Ordonnance Criminelle, Titre 14, Art. 19 (1670) (commentaries to this provision, applicable solely to minor crime, can be found in A. ESMEIN, supra note 11, at 275). This situation persists in modern systems. For a lucid presentation of such devices in West Germany, see J. Langbein, supra note 51.

But where serious offenses are involved, the case must go to trial even if the defendant fully confesses. All that the defendant's confession will effect is the shortening of the relevant criminal process. Nor can the gains to the system be compared with those arising from the avoidance of the Anglo-American trial. For some empirical data on this problem, see Casper \&: Zeisel, supra note 21, at 146.

142. See United States v. Dougherty, 473 F.2d 1113, 1128 (D.C. Cir. 1972) (statutory right under 28 U.S.C. $\$ 1654$ (1970)). On the constitutional right to pro se representation, see Faretta v. California, 43 U.S.L.W. 3301 (U.S., argued Nov. 19, 1974) (No. 73-5772). There is, however, no question about the pro se right in England, where failure to respect it is a ground for appcal. See The King v. Woodward, [1944] 1 K.B. 118.

143. Continental systems ustally speak of "necessary defense" (notwendige Verteidigung). See, e.g., Comparative Crim. Law Project of N.X.U., German Code of Criminal Procedure § 140 (1965) [hereinafter cited as Grrman Code of Criminal Procedure]; Code of Criminat. Procedure of the RSFSR art. 49, in H. Berman, Soviet Criminal Law and Procedure (2d ed. 1972). 
evidence. Continental systems are generally less hospitable to the idea that reliable but illegally obtained evidence should be rejected. Those exclusions that take place are accomplished as part of official duties and, where this occurs, even defendant's consent will not suffice to allow the use of illegally obtained evidence. ${ }^{144}$

Continental lawyers observing the Anglo-American criminal process have voiced fears that entrusting so many decisions to the defendant threatens his interests and may lead as well to objectively false determinations. They note, for instance, that if a defendant-for some reason best known to himself-fails to raise a defense that is both complete in law and supportable in fact, the verdict may go against him and an innocent man thereby be convicted. And they add that when issues of such strategic importance depend on the defendant's will, officials may be tempted to pressure defendants into waiving their rights to the costlier modes of processing.

These and similar objections carry decisive weight in the continental legal system, and find support in the prevailing views of the relationship of state and individual. In the framework of classical liberalism, as expressed, for example, in 19th century utilitarianism, these objections seem far weaker and too rigidly dogmatic. ${ }^{145}$

I could easily continue to enumerate procedural arrangements characteristic of the Anglo-American system of criminal justice that are justifiable in the context of classic English liberalism ${ }^{146}$ but antithetical to all influential continental ideologies. What I have said so

144. Seldom will this be expressed in statutes or codes, for it is considered as selfevident in light of continental "legal science." Occasionally, however, it is expressed in legislative texts. See, e.g., German Code of Criminal. Procedure, supra note $143, \$ 136 a$ (1965).

145. The marriage of classic liberalism and utilitarianism is usually taken for granted. See, e.g., Smith, Liberalism, in 9 INT'L ENCYc. Soc. ScI. 276 (1968). It is, however, a marriage with many strains, especially if classic Benthamite utilitarianism is involved. See J. RAwLs, A THEORY OF Justice 22-23, (1971) (especially at 29, 33). Using the concepts developed by Professor Packer, one is tempted to say that utilitarianism tends toward the "Crime Control Model," while classic liberalism (including some newer accretions with welfare state overtones) espouses the "Due Process Model." See H. PACKER, ThE Limirs of the Criminal Sanction $149-73$ (1968). But on the issue discussed in the text, both marital partners, liberalism and utilitarianism, seem to concur, albeit on different grounds.

146. There is one important difference in continental and Anglo-American thinking about procedural arrangements at trial that is independent of classic liberalism, especially in its historically oldest "negative" strand that was inspired by reactions against monarchical oppression. In approaching the desirability of particular procedural arrangements, continental and Anglo-American lawyers often do not have in mind the same paradigmatic criminal case. The former imagine a case of relatively routine nature in which the hypothesis of guilt is more likely than that of innocence. The paradigm for the latter is a very close, almost Buridanian case. It is true that this difference, if indeed it exists, can be related to liberal fears of governmental persecution of the innocent, but there is a better explanation. All cases come to trial under the continental system, and the pretrial investigation screens out those in which the evidence is insufficient, thus increasing the proportion of cases in which guilt is a likely hypothesis. Cases coming up for trial under the common law system of pleading are not routine and may well be mostly "close cases." 
far, however, is enough to show that classic liberalism would imply both the preference for the adversarial over the nonadversarial style, and the choice of the coordinate over the hierarchical model.147

\section{B. The Genesis of Divergent Attitudes toward Authority}

Although it is evident that continental and English liberal political theories diverge with respect to governmental authority, the source of this divergence is elusive and undetermined. Putting this question in an Anglocentric form, why is it that the Continent is alone in its tolerance of concentrated authority? It has been fashionable, particularly in the last century, to seek the answer in the peculiarity of the English Volksgeist. ${ }^{148}$ But few people nowadays would maintain that ideologies develop independently of their social context, even if, in their philosophies, they attribute autonomy to ideas. It is more likely that we may account for different perceptions of authority by studying the dissimiliar developments of political institutions in England and on the Continent. The roots of these developments are, of course, hidden in the recesses of history. But at least some of them are related to the different manner in which feudalism developed and was overcome on the Continent and in England. Renouncing, therefore, my mainly analytic perspective, I shall in this last part venture a brief historical excursus.

It is well known that feudalism appeared somewhat earlier on the Continent than in England. Many circumstances combined to make the early variant of this socio-economic structure very disrup-

147. The parallels between the liberal ideology and procedural arrangements should not be urged too far. First, liberalism as a political ideology is not without internal conflicts. It seems to vacillate between the desire to limit the role of the state and the desire to seek governmental intervention to enhance individual opportunities. Social ills may sometimes be the consequence of oppressive governmental control; at other times, the result of lack of control. Depending on historical circumstance, the balance between the two strands can cast a classical liberal as either a progressive or conservative.

Second, many characteristics of the Anglo-American administration of justice depart from liberal tenets. Consider only the fashionable emphasis on treatment and rehabilitation. Modeling people according to certain images connotes state concern with persons rather than their activities, and runs contrary to classic liberalism. However, liberalism affected substantive ideas as well as criminal procedure. Especially in debates on the limits of the criminal sanction, classic liberalism is still vital. See Note, Limiting the State Police Power: Judicial Reaction to John Stuart Mill, 37 U. CHI. L. REv. 605 (1970).

148. These views are, I think, effectively criticized by $R$. Cannegem, THE BIRTH of THE ENGLish Common LAw 86 (1973). Similar criticism can be levelled against attempts to explain the many parallels between Anglo-American and classical Roman criminal processes in terms of alleged similarities between the Roman and English "national spirits." A better explanation of these parallels is the similar pattern of structuring political authority in the Roman and English political traditions. Both political cultures display many characteristics of the coordinate model: an elaborate system of checks and balances among autonomous magistracies, duplication of functions, reluctance to abolish obsolete institutions, and slow, adventitious growth instead of deliberate intervention. 
tive of order and unity. The Continent was dismembered into a kaleidoscope of virtually independent provinces, controlled by local feudal lords and only loosely bound into larger political units. In the days of slow communication and rudimentary administrative mechanisms, effective rule from a distant center was virtually impossible. As time passed, strongly entrenched regional and local political institutions crystallized. It was thus difficult for continental rulers to create exclusive states out of the existing loose confederations. To effect this gradual extension of control, rulers dispatched officials to occupy provincial and local positions of authority as agents of the central power. At first these officials were weak and perforce respected local customs and privileges. As they gained strength, however, a centralized, stratified bureaucracy emerged. ${ }^{149}$ In areas where feudal fragmentation had caused disruptions and frustrated economic development, the emerging central rule became associated with order and stability. The final product of this development was the continental absolutist monarchy. Even progressive people who opposed such absolutism believed in the need for strong central rule; when the French Revolution destroyed the old order, for example, royal administration was expanded rather than dismantled.150

It was in these contexts that continental attitudes toward authority were shaped. People became adapted to strong central rule, regarding it as both antagonist and savior. Liberal cynics would probably prefer to say that people became insensitive to the evils of concentrated power in the way that Mithridates became immune to poison: by taking it in increasing doses. ${ }^{151}$ Those who rebelled against power were few, and went to the extreme of viewing the state as intrinsically evil.. ${ }^{152}$ But even when their minds dreamed forward into the ideal

149. See J. Strayer, supra note 36 , at 50-56. The development in Italy was different from the French, and, some may think, deviating from the continental "hicrarchical model", at least as far as the administration of the Communes is concerned. However, even within city-states, more than one layer of judicial administration existed, and judicial office was viewed as a delegated rather than as an autonomous function. See Calisse, $A$ History of Italian Law, in 8 Continental LEGAL History SERIEs 145-46, 165 (1928). The Swiss experience is singular and cannot be discussed here.

150. See A. de Tocqueville, L'ANcien Règime (1933); L. HARTZ, The Liberal Tradition in AMerica 44 (1955).

151. Continentals accept as natural many governmental measures that seem reprehensible to Anglo-American liberals, e.g., the role of identity cards. Moreover, many procedural possibilities in continental systems lie unused out of respect for authority (e.g., some broad testimonial privileges).

152. It is well known that most continental liberals were not as implacably hostile to the state as classic English liberals. They believed in the need for state intervention and unity in order to prevent confusion and anarchy. Freedom to them lay not in independence from the state, but in turning it to liberal purposes, in taking an active part in it. See G. DE Rugciero, supra note 120. OnIy a few continental liberals regarded the state as such with antipathy. See, e.g., W. VON HUMBOLDT, IDEEN zU EINEM VERSUCHE DIE 
stateless future, their imaginations did not envision an individualistic society. In their view man was ultimately a social being, a Gattungswesen. Significantly, when these continental rebels inspired mass movements, the exigencies of the revolutionary present were said to preempt visions of the stateless tomorrow. The concentration of power was declared an historical necessity, many social institutions were absorbed into the fabric of the state, and the stateless future was placed "on the other side of history."

The English experience was quite different and in some ways rather unique. Prior to the advent of feudalism, local notables were all but wiped out by successive invasions of the British Isles; the Norman kings, who imported feudalism, were sufficiently farsighted not to grant large, compact landholdings to their vassals. As a result, strong local power centers did not emerge. There was also the crucial circumstance of small scale, which allowed direct and very effective royal intervention throughout the land. There was no need for kings to establish a large central bureaucracy as a transmission mechanism between them and local government. Local notables, not strong enough to be feared, worked in the local administration without pay, thereby eliminating a major expense for the Crown. ${ }^{153}$

Notwithstanding great royal power, however, English feudalism managed to establish a measure of what we would now call constitutional restraint on its monarchs, ${ }^{154}$ and this in the context of a feudalism that was not nearly as disruptive and centrifugal as its continental counterpart. The chaotic War of the Roses was, admittedly, succeeded by a brief intermezzo of Tudor absolutism, but this was neither so rigid nor so enduring as its later continental counterparts. The fight of the middle class against feudal restrictions resulted in the supremacy of the Parliament and a generally less radical break with the not-so-abhorrent past than was later the case in France.

This moderate social change preserved many ancient forms of government by nobility and arrested the development of modern bureaucracies. An essentially local administration by notables prevailed in England well into the 19th century; ${ }^{155}$ indeed, because the age of administrative reforms in England was also the zenith of laissez-faire,

Grenzen der WirksamketT des StaAtes zu bestimmen (1851). Some continental outcrics igainst the state, such as the Nietzschean so wenig Staat wie möglich (as little state as possible), were placed in such ambivalent intellectual contexts that they were even exploited by totalitarian ideologtres.

153. See J. STRAYER, supra note 36 , at $36 \cdot 37,47$.

154. See W. Ulmann, The Individual and Society in the Middle Ages 51 (1966).

155. For additional details, see L. Namier, England IN THE AGE OF THE AMERIGAN Rrvolution, 3-41 (2d ed. 1961). 
strong centralization was never truly considered as an alternative to many increasingly obsolete administrative arrangements. While some reforms affected the administration of the criminal law, many archaic procedural ideas, some of them vestiges from the days of the emerging state, suddenly accorded with the prevailing philosophy of individualism and limited government. Rather than being rejected, they were refurbished and incorporated in the system of criminal justice which slowly assumed its present contours. ${ }^{156}$ "The importance of being. antiquated"157 was thus vindicated with the second turn of the historical spiral. In the whole of the English experience, there is little that could have conditioned people to accept a strongly centralized bureaucratic machinery as a conditio sine qua non of societal order.

Transplanted to America, the classic liberal ethos fell upon fertile soil. Feudalism as a socio-economic order was skipped altogether, and strong centralist rule was never part of the national experience. While the distant English rule inspired colonists with resentment of authority, the overthrow of English dominion did not require the strong arm of concentrated power. In addition, such circumstances as the frontier society, the natural abundance of resources, and the religious legacies of 17 th century Protestantism, facilitated the introduction of liberal dispositions toward authority into the American political culture to an extent astonishing even to English 19th century liberals. People never became mithridated by concentrated power. ${ }^{158}$ It is only around the middle of the last century that the partnership between liberalism and diffuse authority came under great strain. The crises

156. Of course, some important differences between the criminal process on the Continent and in England antedated the 19th century reforms. The 13th century papal prohibition of clergy participation in trials by ordeal triggered the divergence of the two systems, although they had begun to drift apart even before. This prohibition created a vacuum in the administration of justice which was filled by different procedural arrangements in England and continental Europe. For modern perspectives on this development see R. CAENEGEM, supra note 148 , at 84 .

The adversarial style of processing criminal matters is largely a product of the early 19th century. Until the middle of that century, the pretrial phase of the process was essentially a type of judicial investigation along inquisitorial lines conducted by justices of the peace. Nor was the trial an adversary battle of counsel. Lawyers would seldom appear for the prosecution, and defense counsel were not admitted in ordinary felony cases until 1837. In this situation the judge called witnesses and examined them, and in the century prior, had also interrogated the defendant. For an account of such judicial trial examination, see Fielding's picaresque novel Tom Jones. H. Fifiding, THE History of ToM Jones, book 8, ch. 11 (1906).

Evidentiary and procedural finesse, so characteristic of the adversary process, could not develop in the context of a trial without lawyers. Indeed, until the modern era, there were no law reports of criminal cases. For a realistic account of the criminal process prior to modern times, see S. Minsom, supra note 79, at 353-74.

157. The phrase has been borrowed from another context in R. CAENEGEM, supra note 148 , at 84 .

158. See L. HARTZ, supra note 150, at 39-50; G. Wood, supra note 133, at 150-51, 604. Perceived needs for order, so important for the opposition between the coordinate and hierarchical model, may be related to the experience with political authority. 
of slavery and secession forced many liberal minds to turn to central authority as a guarantor of liberal values. It is true that, as our century progresses, many tenets of classic liberalism increasingly clash with new realities, but no alternative social theory has emerged as a dominant ideological force.

The administration of criminal law is one area in which the continued vitality of liberalism is very much in evidence, notwithstanding strong counterpressures generated by the modern system of mass criminal justice. ${ }^{159}$ And the specter of imperious and oppressive governmental inteference in the life of the individual is still a powerful generator of procedural choices.

\section{Epilogue}

In the first part of this article, the "hierarchical" model of authority was outlined and used to illuminate salient aspects of the continental procedural system. In the second part, the "coordinate" model was sketched and its explanatory power demonstrated by considering actual Anglo-American criminal processes. This description showed that the two systems differ significantly in the extent of the centralization of authority, the degree of its rigidity, the choice between determinative and flexible rules, the importance attached to formality and documentation, and the types of behavior expectations held by government officials.

Using this framework I next examined the connection between authority structures and criminal processing styles. Finally, I left the legal arena altogether and trespassed into the realm of political ideology. Although my narrative has not proceeded in an historical vacuum, I have not intended it primarily as a study, however superficial, of the genesis of legal phenomena. Rather, I have suggested some fundamental conceptual relationships that link certain political ideologies and particular forms of criminal justice systems.

Even if my unpardonable abridgment of history has persuaded the reader that the singular characteristics of the Anglo-American criminal process can be related to unique liberal dispositions toward gov-

159. Pressures of modern mass criminal justice to discard liberal ideology were brilliantly described by H. PACKER, supra note 145 , at 149.73, in his depiction of the "Crime Control Model." Some procedural reforms instituted by the Supreme Court, during the 1960 's, imposing positive duties on the government to help the indigent, may arguably be interpreted as a departure from classic laissez-faire. See, e.g., Douglas v. California, 372 U.S. 353 (1963); Gideon v. Wainwright, 372 U.S. 335 (1963); Griffin v. Illinois, 351 U.S. 12 (1956). 
ernment authority, the reader who likes to take sociological theory with his history will probably want to continue the search for more basic factors. My discussion has already unveiled a larger problem by implication. Throughout this article I have treated continental sys. tems as a group, lumping together Western democracies and Marxian socialist countries. This I have done in the belief that great differences among various continental systems of criminal justice pale in significance when contrasted with the Anglo-American. Does my position imply that, at least as far as the organization of procedural authority and the type of processing style are concerned, attitudes toward political authority are more important sources of procedural divergences than the social and economic structure of society? ${ }^{100}$ This larger question comes tantalizingly close to my theme, but I must leave it aside because of the great complexity of problems involved in answering it. Thus, there is no dénouement to issues raised by this article, and I can unfortunately offer no deeply satisfying synthesis to the reader patient enough to follow me to the end.

160. This is inseparable from the fascinating and urgent problem of how the distinction between continental and common law legal systems relates to the opposition between capitalism and socialism. 